The final publication is available at Elsevier via https://doi.org/10.1016/j.gca.2015.02.025 (C) 2015. This manuscript version is made available under the CC-BY-NC-ND 4.0 license http://creativecommons.org/licenses/by-nc-nd/4.0/

\title{
Uranium and molybdenum isotope evidence for an episode of widespread ocean oxygenation during the late Ediacaran Period
}

Brian Kendall ${ }^{\mathrm{a}, \mathrm{b},{ }^{*}}$, Tsuyoshi Komiya ${ }^{\mathrm{b}, \mathrm{c}, \mathrm{d}}$, Timothy W. Lyons ${ }^{\mathrm{e}}$, Steve M. Bates ${ }^{\mathrm{e}}$, Gwyneth W. Gordon $^{\mathrm{b}}$, Stephen J. Romaniello ${ }^{\mathrm{b}}$, Ganqing Jiang ${ }^{\mathrm{f}}$, Robert A. Creaser ${ }^{\mathrm{g}}$, Shuhai Xiao ${ }^{\mathrm{h}}$, Kathleen McFadden ${ }^{\mathrm{i}}$, Yusuke Sawaki ${ }^{\mathrm{j}}$, Miyuki Tahata ${ }^{\mathrm{k}}$, Degan Shu ${ }^{1}$, Jian Han ${ }^{1}$, Yong Li ${ }^{\mathrm{m}}$, Xuelei Chu ${ }^{\mathrm{n}}$, Ariel D. Anbar ${ }^{\mathrm{b}, \mathrm{o}}$

${ }^{a}$ Department of Earth and Environmental Sciences, University of Waterloo, 200 University Avenue West, Waterloo, Ontario, Canada N2L 3G1

${ }^{\mathrm{b}}$ School of Earth and Space Exploration, Arizona State University, Tempe, AZ 85287, USA

c Department of Earth Science and Astronomy, The University of Tokyo, 3-8-1 Komaba, Meguro-ku, Tokyo, 153-8902, Japan

${ }^{\mathrm{d}}$ Research Center for the Evolving Earth and Planets, Tokyo Institute of Technology, 2-12-1 Ookayama, Meguro-ku, Tokyo 152-8551, Japan

${ }^{\mathrm{e}}$ Department of Earth Sciences, University of California, Riverside, CA 92521, USA

${ }^{\mathrm{f}}$ Department of Geoscience, University of Nevada, Las Vegas, NV 89154, USA

${ }^{\mathrm{g}}$ Department of Earth and Atmospheric Sciences, University of Alberta, Edmonton, Alberta T6G 2E3, Canada

h Department of Geosciences, Virginia Polytechnic Institute and State University, Blacksburg, VA 24061, USA

${ }^{\mathrm{i}}$ ConocoPhillips, Houston, TX 77079, USA 
j Institute for Research on Earth Evolution, Japan Agency for Marine-Earth Science and Technology, 2-15 Natsushima-Cho, Yokosuka-city, Kanagawa 237-0061, Japan

${ }^{\mathrm{k}}$ Department of Earth and Planetary Sciences, Tokyo Institute of Technology, 2-12-1 Ookayama, Meguro-ku, Tokyo, 152-8551, Japan

${ }^{1}$ Department of Geology and Key Laboratory for Continental Dynamics, Northwest University, Xi'an, 710069, China

${ }^{\mathrm{m}}$ School of Earth Sciences and Resources Management, Chang'an University, Xi'an 710054, China

${ }^{\mathrm{n}}$ Institute of Geology and Geophysics, Chinese Academy of Sciences, Beijing 100029, China

${ }^{\circ}$ Department of Chemistry and Biochemistry, Arizona State University, Tempe, AZ 85287, USA

Manuscript accepted for Geochimica et Cosmochimica Acta

2015

https://doi.org/10.1016/i.gca.2015.02.025

*Corresponding author at: Department of Earth and Environmental Sciences, University of Waterloo, 200 University Avenue West, Waterloo, Ontario, Canada N2L 3G1.

Email: bkendall@uwaterloo.ca 


\section{Abstract}

To improve estimates of the extent of ocean oxygenation during the late Ediacaran Period, we measured the $\mathrm{U}$ and Mo isotope compositions of euxinic (anoxic and sulfidic) organic-rich mudrocks (ORM) of Member IV, upper Doushantuo Formation, South China. The average $\delta^{238} \mathrm{U}$ of most samples is $0.24 \pm 0.16 \%$ (2SD; relative to standard CRM145), which is slightly higher than the average $\delta^{238} U$ of $0.02 \pm 0.12 \%$ for restricted Black Sea (deep-water Unit I) euxinic sediments and is similar to a modeled $\delta^{238} \mathrm{U}$ value of $0.2 \%$ for open ocean euxinic sediments in the modern well-oxygenated oceans. Because ${ }^{238} \mathrm{U}$ is preferentially removed to euxinic sediments compared to ${ }^{235} \mathrm{U}$, expanded ocean anoxia will deplete seawater of ${ }^{238} \mathrm{U}$ relative to ${ }^{235} \mathrm{U}$, ultimately leading to deposition of ORM with low $\delta^{238} \mathrm{U}$. Hence, the high $\delta^{238} \mathrm{U}$ of Member IV ORM points to a common occurrence of extensive ocean oxygenation ca. 560 to 551 Myr ago.

The Mo isotope composition of sediments deposited from strongly euxinic bottom waters $\left(\left[\mathrm{H}_{2} \mathrm{~S}\right]_{\mathrm{aq}}>11 \mu \mathrm{M}\right)$ either directly records the global seawater Mo isotope composition (if Mo removal from deep waters is quantitative) or represents a minimum value for seawater (if Mo removal is not quantitative). Near the top of Member IV, $\delta^{98}$ Mo approaches the modern seawater value of $2.34 \pm 0.10 \%$. High $\delta^{98}$ Mo points to widespread ocean oxygenation because the preferential removal of isotopically light Mo to sediments occurs to a greater extent in $\mathrm{O}_{2}$-rich compared to $\mathrm{O}_{2}$-deficient marine environments. However, the $\delta^{98}$ Mo value for most Member IV ORM is near $0 \%$ (relative to standard NIST SRM $3134=0.25 \%$ ), suggesting extensive anoxia. The low $\delta^{98}$ Mo is at odds with the high Mo concentrations of Member IV ORM, which suggest a large seawater Mo inventory in well-oxygenated oceans, and the high $\delta^{238} \mathrm{U}$. Hence, we propose that the low $\delta^{98}$ Mo of most Member IV ORM was fractionated from contemporaneous seawater. 
24 Possible mechanisms driving this isotope fractionation include: (1) inadequate dissolved sulfide

25 for quantitative thiomolybdate formation and capture of a seawater-like $\delta^{98}$ Mo signature in 26 sediments or (2) delivery of isotopically light Mo to sediments via a particulate Fe-Mn 27 oxyhydroxide shuttle.

A compilation of Mo isotope data from euxinic ORM suggests that there were transient

29 episodes of extensive ocean oxygenation that break up intervals of less oxygenated oceans 30 during late Neoproterozoic and early Paleozoic time. Hence, Member IV does not capture 31 irreversible deep ocean oxygenation. Instead, complex ocean redox variations likely marked the 32 transition from $\mathrm{O}_{2}$-deficient Proterozoic oceans to widely oxygenated later Phanerozoic oceans.

\section{INTRODUCTION}

High concentrations of environmental oxygen are a physiological requirement for the

37 evolution of metabolically active metazoans capable of movement and predation (Towe, 1970;

38 Runnegar, 1991; Knoll and Carroll, 1999; Knoll, 2011). The time when this requirement was met

39 is not precisely known. Furthermore, there is debate about whether or not environmental

40 oxygenation is the main driver of trends in early metazoan evolution, once the physiological

41 requirement was met. Some studies highlight a direct connection between the initial

42 diversification of Ediacaran metazoans and ocean oxygenation, for example, in the aftermath of

43 the ca. 635 Ma end-Cryogenian glaciation (Planavsky et al., 2010; Sahoo et al., 2012).

44 Alternatively, a significant time lag between the attainment of sufficient oxygen levels and the

45 diversification of metazoans may have arisen from genetic and ecological factors (Erwin et al.,

46 2011; Mills et al., 2014; Penny et al., 2014; Planavsky et al., 2014). The appearance of more 
47 complex eukaryotes, including early metazoans, may have led to more extensive ocean

48 oxygenation (Butterfield, 2009; Lenton et al., 2014). Environmental and ecological triggers may

49 have acted in tandem to drive metazoan diversification, culminating in the Cambrian Explosion

50 (Sperling et al., 2013a). Understanding the relationship between environmental oxygen levels

51 and metazoan evolution ultimately requires higher resolution geochemical, geochronological,

52 and biostratigraphic data, as well as improved quantitative constraints on spatiotemporal changes

53 in atmosphere and ocean redox conditions (e.g., Och and Shields-Zhou, 2012; Lowenstein et al.,

54 2014; Lyons et al., 2014).

55 Geochemical proxies for the extent of ocean oxygenation during the Ediacaran Period 56 suggest a time of complicated redox changes. High concentrations of the redox-sensitive metals

57 Mo and V are found in the earliest Ediacaran (ca. $632 \mathrm{Ma}$ ) organic-rich mudrocks (ORM) of the

58 Doushantuo Formation (South China). The high Mo and V concentrations point to a larger

59 oceanic Mo and V inventory as a result of increased deep ocean oxygenation (Sahoo et al.,

60 2012). However, there is no compelling evidence for extensive oxygenation during the remainder

61 of the early Ediacaran Period. For example, sedimentary Fe speciation, S and Fe isotope data,

62 and low Mo concentrations in ORM suggest widely anoxic oceans containing low marine sulfate

63 concentrations (Canfield et al., 2008; McFadden et al., 2008; Li et al., 2010; Fan et al., 2014;

64 Guan et al., 2014). These data suggest that the oceans largely retained a Proterozoic-style, redox65 stratified character during the early Ediacaran Period.

66 There is geochemical evidence to support episodes of late Ediacaran ocean oxygenation.

67 Although sedimentary Fe speciation data continue to point to regions of at least locally anoxic

68 deep oceans (Canfield et al., 2008; Li et al., 2010; Frei et al., 2013; Johnston et al., 2013), the

69 same proxy suggests that parts of the deep ocean became oxygenated after the end of the ca. 580 
Ma Gaskiers glaciation (Canfield et al., 2007, 2008; Johnston et al., 2012a). High Mo

71 concentrations in ca. 560-551 Ma ORM of Member IV, upper Doushantuo Formation (South

72 China), point to a more globally oxygenated state for the oceans (Scott et al., 2008; Li et al., 73 2010; Och and Shields-Zhou, 2012). However, the absence of evidence for late Ediacaran ocean

74 oxygenation in some ocean basins has led some researchers to question the extent of oxygenation

75 (Johnston et al., 2013). The isotopic compositions of $U$ and Mo in anoxic and sulfidic (euxinic)

76 ORM are a promising approach for constraining the global extent of ancient ocean oxygenation

77 (Arnold et al., 2004; Weyer et al., 2008). Here, we present new U and Mo isotope data from

78 Member IV ORM that provide further evidence for extensive ocean oxygenation ca. 560-551

79 Myr ago. We also present an updated Mo isotope compilation for ORM that suggests multiple

80 transient episodes of widespread ocean oxygenation occurred at the Precambrian-Phanerozoic 81 transition.

82

\section{MEMBER IV, DOUSHANTUO FORMATION, SOUTH CHINA}

87 Rodinia (Wang and Li, 2003; Jiang et al., 2003). The Doushantuo Formation is underlain by 88 glacial diamictites of the Nantuo Formation, deposited during the widespread end-Cryogenian 89 glaciation, and is overlain by carbonates of the latest Ediacaran Dengying Formation. In the 90 Three Gorges region, located $\sim 30 \mathrm{~km}$ west of Yichang (Fig. 1), the Doushantuo Formation was 91 deposited on the inner shelf (Western Hubei Platform) below wave base (McFadden et al., 2008;

92 Jiang et al., 2011). Here, the formation is up to $250 \mathrm{~m}$ thick and comprises a basal $\sim 5 \mathrm{~m}$ thick 
93 dolostone (Member I), interbedded ORM and dolostones containing abundant chert nodules

94 (Member II), dolostone that passes into interbedded limestone and dolomitic mudstone (Member 95 III), and a 5-15 m thick interval of ORM (Member IV) (Fig. 2, Zhou and Xiao, 2007; 96 McFadden et al., 2008; Sawaki et al., 2010; Jiang et al., 2011).

Fossil assemblages in the Doushantuo Formation and correlatives include macroscopic 98 carbonaceous compressions of eukaryotes, multicellular algae, acanthomorph acritarchs, and 99 possible animal eggs and embryos (Xiao et al., 2002; Yin et al., 2007; McFadden et al., 2008; 100 Yuan et al., 2011; Schiffbauer et al., 2012; Chen et al., 2014). Alternative interpretations for 101 these embryo-like fossils, such as non-metazoan holozoans (Huldtgren et al., 2011) or sulfur 102 bacteria (Bailey et al., 2007), are inconsistent with their morphology, taphonomy and 103 multicellularity (Xiao et al., 2007, 2012; Schiffbauer et al., 2012; Chen et al., 2014). The 104 overlying carbonates of the latest Ediacaran Dengying Formation preserve macroscopic 105 metazoan body fossils, biomineralizing metazoans (e.g., Cloudina and Sinotubulites), and large 106 horizontal trace fossils made by motile bilaterians (Xiao et al., 2005; Weber et al., 2007; Chen et 107 al., 2008).

To obtain better quantitative constraints on the extent of late Ediacaran ocean oxygenation, we measured $\mathrm{U}$ and Mo isotope compositions, Fe speciation, and total organic 110 carbon (TOC) concentrations for the Member IV ORM. Our measurements were obtained from 111 the well-studied Jiulongwan outcrop section, Three Gorges region (McFadden et al., 2008), plus 112 a recently drilled core collected $5 \mathrm{~km}$ farther southwest (Site 1 of Sawaki et al., 2010) to test 113 lateral homogeneity of the data and to verify that deleterious oxidative weathering was 114 negligible. Previous work has revealed high Mo concentrations in Member IV, which most likely 115 requires a large dissolved Mo reservoir, suggesting both significant ocean oxygenation and a 
good connection between the Nanhua Basin and open ocean (Scott et al., 2008; Sahoo et al., 2012).

Precise absolute age constraints for the duration of Member IV deposition have been challenging to obtain. The end of Member IV deposition is well-constrained by a U-Pb zircon age of 551.1 $\pm 0.6 \mathrm{Ma}$ (Mean Square of Weighted Deviates $[\mathrm{MSWD}]=0.48$ ) from an ash bed nearly $1 \mathrm{~m}$ below the top of the member (from the Jiuqunao section located $\sim 20 \mathrm{~km}$ northwest of the Three Gorges region; Condon et al., 2005). However, the onset of Member IV deposition is poorly constrained. The top of Member IV (ca. $551 \mathrm{Ma}$ ) marks the end of a prominent negative $\delta^{13} \mathrm{C}$ excursion that began in Member III (Jiang et al., 2007; Zhou and Xiao, 2007; Zhu et al., 2007; McFadden et al., 2008; Sawaki et al., 2010). This excursion has been correlated with the Shuram $\delta^{13} \mathrm{C}$ excursion in Oman (Fike et al., 2006; Le Guerroué, 2010), the Wonoka $\delta^{13} \mathrm{C}$ excursion in Australia (Calver, 2000; Retallack et al., 2014), and the Krol B $\delta^{13} \mathrm{C}$ excursion in India (Kaufman et al., 2006; Jiang et al., 2007). Although there is no absolute age constraint for the duration of this $\delta^{13} \mathrm{C}$ excursion in any of these successions, stratigraphic analyses and $\mathrm{Sr}$ isotope data suggest that the Doushantuo-Shuram-Wonoka-Krol isotope anomaly is younger than the Gaskiers glaciation (Calver, 2000; Fike et al., 2006; Le Guerroué, 2010; Sawaki et al., 2010). This interpretation is in line with the suggestion that the stratigraphic break at the Member II-III transition reflects sea-level fall during the Gaskiers glaciation and is thus ca. $580 \mathrm{Ma}$ (Condon et al., 2005; Tahata et al., 2013). Considering that the Doushantuo Formation (ca. 635-551 Ma) covers $\sim 90 \%$ of Ediacaran time, a simple age extrapolation would place the base of Member IV at ca. $560 \mathrm{Ma}$ (e.g., Jiang et al., 2007). This estimate is consistent with a $\mathrm{Pb}-\mathrm{Pb}$ age of $576 \pm 14$ Ma (MSWD = 0.4) from the upper phosphorite layers (Member III correlative) of the Doushantuo Formation in Weng'an, located $750 \mathrm{~km}$ to the southwest of the Three Gorges region 
139 (Chen et al., 2004), and the similarity of acritarch fossils between the Jiulongwan and Weng'an 140 sections (e.g., Zhou et al., 2007; Xiao et al., 2014).

Recently, a Re-Os age of $595 \pm 22 \mathrm{Ma}(\mathrm{MSWD}=29)$ was reported from ORM at the

142 base of Member IV in the Jiulongwan section (Zhu et al., 2013). A more precise Re-Os age of $143591.1 \pm 5.3 \mathrm{Ma}(\mathrm{MSWD}=1.3)$ was derived from a subset of four analyses that made up the 7-

144 point Re-Os isochron regression of $595 \pm 22 \mathrm{Ma}$. Zhu et al. (2013) attributed the excess scatter in 145 the 7-point regression to initial ${ }^{187} \mathrm{Os} /{ }^{188}$ Os heterogeneity (i.e., variations in seawater ${ }^{187} \mathrm{Os} /{ }^{188} \mathrm{Os}$ )

146 rather than post-depositional disturbance. However, the seven samples were obtained from a 147 lateral interval of only $\sim 5$ to $10 \mathrm{~cm}$ thick, raising doubts about whether variations in seawater $148{ }^{187} \mathrm{Os} /{ }^{188}$ Os can explain the high MSWD. As discussed below, the basal Member IV ORM from 149 the Jiulongwan section have unusual Mo and $U$ isotope signatures, which may reflect post150 depositional modification that could have had an adverse effect on the Re-Os age of Zhu et al. 151 (2013). In addition, the Re-Os age of ca. 591 Ma implies that the $\leq 10$-m-thick Member IV black 152 shales span 40 Myr of time. This is unlikely unless a major unconformity or hiatus is found 153 within Member IV in future studies. Therefore, we prefer to estimate the age of Member IV as 154 ca. 560-551 Ma.

\section{ANALYTICAL METHODS}

\subsection{Uranium isotopes}

All U and Mo isotope data were obtained at the W. M. Keck Foundation Laboratory for University. Uranium isotope measurements were made following the protocols outlined in 
162 Weyer et al. (2008) and Kendall et al. (2013). Powdered sample splits (75-100 mg) were ashed 163 overnight at $550^{\circ} \mathrm{C}$ and dissolved completely by $\mathrm{HF}-\mathrm{HNO}_{3}-\mathrm{HCl}$ acid digestion. A split of the 164 sample solution was diluted with $2 \% \mathrm{HNO}_{3}$ and analyzed for $\mathrm{U}$ concentrations on a Thermo 165 Scientific $\mathrm{X}$ series quadrupole ICP-MS (inductively coupled plasma mass spectrometer). 166 Instrument accuracy was verified using secondary standard solutions, including the USGS 167 Devonian black shale standard SDO-1. Analyte concentration reproducibility was within 5\%. Uranium isotope compositions were measured on a Thermo Scientific Neptune multi169 collector ICP-MS using a ${ }^{236} \mathrm{U}:{ }^{233} \mathrm{U}$ double spike (IRMM-3636; Verbruggen et al., 2008) to 170 correct for instrumental mass bias. The spike was equilibrated with sample solutions, and U was 171 subsequently isolated from the sample-spike mixture using Eichrom ${ }^{\circledR}$ UTEVA resin. Sample $172 \delta^{238} \mathrm{U}$ is reported as per mil deviations from the CRM145 standard $\left[\delta^{238} \mathrm{U}=\right.$ $\left.173\left({ }^{238 / 235} U_{\text {sample }}{ }^{238 / 235} U_{\text {standard }}-1\right) \times 1000\right]$. Repeated measurements of the $U$ isotope standards 174 SRM950a and CRM129a yielded average $\delta^{238} \mathrm{U}$ values of $0.04 \pm 0.06 \%(2 \mathrm{SD} ; \mathrm{n}=38)$ and $1751.72 \pm 0.09 \%$ o $(2 \mathrm{SD} ; \mathrm{n}=124)$, respectively. Hence, $\mathrm{U}$ isotope data reported relative to CRM145 176 are statistically identical to $U$ isotope data reported relative to SRM950a (e.g., Weyer et al., 177 2008; Montoya-Pino et al., 2010; Brennecka et al., 2011a, b; Kendall et al., 2013). We also 178 measured four full powder replicates of SDO-1 during the course of this study, and these 179 analyses gave an average of $-0.06 \pm 0.04 \%(2 \mathrm{SD} ; \mathrm{n}=17)$. We report the $2 \mathrm{SD}$ uncertainty of a 180 sample as the 2SD uncertainty of sample replicate measurements or $0.07 \%$ (average of the 181 uncertainties given above for SRM950a, CRM129a, and SDO-1), whichever is greater. 


\subsection{Molybdenum isotopes}

Molybdenum concentration and isotope data were obtained following the methods outlined in Kendall et al. (2009a) and Duan et al. (2010). After sample dissolution using the methods outlined above, samples were purified for Mo using anion and cation exchange chromatography. For each sample, Mo concentrations were measured before and after chromatography to verify that column yields were $>95 \%$. For optimal precision of column yield measurements, Mo concentrations were determined by isotope dilution quadrupole ICP-MS, and all of the digested sample solution was used for column chemistry (hence, separate splits of the sample powders were used for Mo and $\mathrm{U}$ isotope measurements). The Mo isotope compositions were measured by multi-collector ICP-MS using sample-standard bracketing and a $\mathrm{Zr}$ element spike (prepared from Johnson Matthey Specpure® Zr plasma standard solution; Lot \#700193E) to correct for instrumental mass fractionation (these measurements were done before implementation of the Mo double spike technique at Arizona State University). Our Mo isotope data were originally measured relative to the Johnson Matthey Specpure® Mo plasma standard (Lot \#802309E; RochMo2).

Sample $\delta^{98}$ Mo was re-calculated as per mil deviations from the new international NIST SRM 3134 standard as follows: $\delta^{98} \mathrm{Mo}=\left[{ }^{98 / 95} \mathrm{Mo}_{\text {sample }} /\left({ }^{98 / 95} \mathrm{Mo}_{\text {standard }} * 0.99975\right)-1\right] \times 1000$ (Goldberg et al., 2013; Nägler et al., 2014). The logic behind setting the NIST SRM 3134 standard to $0.25 \%$ (instead of $0 \%$ ) is to retain comparison of sample $\delta^{98}$ Mo data with the "traditional" seawater $\delta^{98}$ Mo value of 2.3\%o (Nägler et al., 2014). On this scale, seawater has a value of $2.34 \pm 0.10 \%$, and RochMo2 has a value of $-0.08 \pm 0.05 \%$ (Goldberg et al., 2013; Nägler et al., 2014). For an eighteen month period covering the Mo isotope analyses in this study, the average $\delta^{98}$ Mo for SDO-1, based on five separate powder digestions, was $0.83 \pm 0.15$ 
$208 \%$ relative to NIST SRM $3134=0 \%$ or $1.08 \pm 0.15 \%$ relative to NIST SRM $3134=0.25 \%$

209 (2SD, $n=238$ ). The first value is in excellent agreement with the SDO-1 average of $0.80 \pm 0.14$

210 \%o reported by Goldberg et al. (2013). Given the average uncertainty of SDO-1, we report the

211 2SD uncertainty of a sample as the 2SD uncertainty of sample replicate measurements or 0.15

$212 \%$, whichever is greater.

213

$214 \quad 3.3$ Sedimentary iron speciation

215 Preservation of seawater $\delta^{98} \mathrm{Mo}$ is most likely to occur in ORM deposited beneath 216 strongly euxinic bottom waters (Barling et al., 2001; Arnold et al., 2004; Neubert et al., 2008;

217 Gordon et al., 2009). Hence, sedimentary Fe speciation was used to reconstruct local bottom 218 water redox conditions at the studied localities. Transport, scavenging, and enrichment of Fe 219 occur in modern anoxic marine basins. The sediments accumulating in such settings have ratios 220 of biogeochemically highly reactive $\mathrm{Fe}\left(\mathrm{Fe}_{\mathrm{HR}}\right)$ to total $\mathrm{Fe}\left(\mathrm{Fe}_{\mathrm{T}}\right)$ that are higher (typically >0.38) 221 compared to modern sediments $(0.26 \pm 0.08)$ and Phanerozoic sedimentary rocks $(0.14 \pm 0.08)$ 222 deposited from oxygenated bottom waters (Raiswell and Canfield, 1998; Poulton and Raiswell, 223 2002; Lyons and Severmann, 2006). Biogeochemically highly reactive $\mathrm{Fe}\left(\mathrm{Fe}_{\mathrm{HR}}\right)$ is defined as 224 pyrite $\mathrm{Fe}\left(\mathrm{Fe}_{\mathrm{PY}}\right)$ and other Fe phases (carbonates $\left[\mathrm{Fe}_{\mathrm{Carb}}\right]$, ferric oxides $\left[\mathrm{Fe}_{\mathrm{Ox}}\right]$, and mixed-valence 225 Fe oxides, primarily magnetite $\left.\left[\mathrm{Fe}_{\mathrm{Mag}}\right]\right)$ that will react with sulfide in the water column or in 226 sediments during early diagenesis. Hence, $\mathrm{Fe}_{\mathrm{HR}}=\mathrm{Fe}_{\mathrm{PY}}+\mathrm{Fe}_{\mathrm{Carb}}+\mathrm{Fe}_{\mathrm{Ox}}+\mathrm{Fe}_{\mathrm{Mag}}$ (Poulton et al., 227 2004; Poulton and Canfield, 2005). The modern baseline for $\mathrm{Fe}_{\mathrm{HR}} / \mathrm{Fe}_{\mathrm{T}}$ was derived using $\mathrm{Fe}_{\mathrm{HR}}=$ $228 \mathrm{Fe}_{\mathrm{PY}}$ (pyrite) $+\mathrm{Fe}_{\mathrm{Ox}}$ (ferric oxides) (Raiswell and Canfield, 1998). Although $\mathrm{Fe}_{\mathrm{HR}}$ has been 229 expanded to include $\mathrm{Fe}_{\mathrm{Carb}}$ (carbonates) and $\mathrm{Fe}_{\mathrm{Mag}}$ (mixed-valence Fe oxides) because of their 230 importance in ancient ORM (Poulton et al., 2004; Poulton and Canfield, 2005), comparison with 
231 the modern baseline is still justified given the scarcity of $\mathrm{Fe}_{\mathrm{Carb}}$ and $\mathrm{Fe}_{\mathrm{Mag}}$ in modern sediments.

232 The extent to which $\mathrm{Fe}_{\mathrm{HR}}$ has been converted to pyrite (FepY) is used to determine if the bottom 233 waters were euxinic $\left(\mathrm{Fe}_{\mathrm{PY}} / \mathrm{Fe}_{\mathrm{HR}}>0.7\right)$ or ferruginous $\left(\mathrm{Fe}_{\mathrm{PY}} / \mathrm{Fe}_{\mathrm{HR}}<0.7\right)$ (some studies use the 234 older boundary value of 0.8; Anderson and Raiswell, 2004; Poulton et al., 2004; Poulton and 235 Canfield, 2011).

236 Sedimentary Fe speciation analyses were carried out at the University of California, 237 Riverside. A sequential extraction method (Poulton and Canfield, 2005), followed by analysis on 238 an Agilent 7500ce ICP-MS, was used to determine $\mathrm{Fe}_{\mathrm{Carb}}+\mathrm{Fe}_{\mathrm{Ox}}+\mathrm{Fe}_{\mathrm{Mag}}$ (Li et al., 2010). 239 Analytical reproducibility was typically within 5\%, with the exception of some low-Fe samples $240(<0.1 \mathrm{wt} \%)$. Pyrite Fe was determined from the weight percent of S extracted during a 2-hour 241 chromium chloride distillation, assuming a stoichiometry of $\mathrm{FeS}_{2}$.

\section{$243 \quad 3.4$ Total organic carbon}

Measurements of total organic carbon (TOC) were made at the Japan Agency of Marine-

245 Earth Science and Technology (JAMSTEC) and are described in Kikumoto et al. (2014). A 246 known amount of powdered sample was first demineralized by $10 \mathrm{M} \mathrm{HCl}$ at $70^{\circ} \mathrm{C}$ for $>24$ hours.

247 Residues were rinsed with pure water and ethanol, dried, weighed, and combusted at $1000^{\circ} \mathrm{C}$ 248 with an elemental analyzer (EA) connected to a Finnigan Delta XP mass spectrometer. 249 Abundances of the resultant $\mathrm{CO}_{2}$ gas were measured by a conventional EA-IRMS method. 250 Additional TOC measurements, derived from the difference between total carbon (determined by 251 combustion) and total inorganic carbon (determined by acidification), were made using an Eltra 252 CS-500 carbon/sulfur analyzer at the University of California, Riverside, as described in Scott et 
253 al. (2008) and Li et al. (2010). For both methods, the analytical reproducibility of TOC contents

254 is $0.10 \mathrm{wt} \%$ or better based on repeated analyses of standards.

\section{RESULTS}

\subsection{Sedimentary iron speciation and metal concentrations}

All samples from the Jiulongwan outcrop section and the Site 1 drill core section have $260 \mathrm{Fe}_{\mathrm{HR}} / \mathrm{Fe}_{\mathrm{T}}>0.38$ and $\mathrm{Fe}_{\mathrm{PY}} / \mathrm{Fe}_{\mathrm{HR}}>0.7$, indicating that the inner shelf was persistently covered by 261 euxinic bottom waters during deposition of Member IV, consistent with prior data (Table 1 and 262 Fig. 2; Scott et al., 2008; Li et al., 2010). This interpretation is further supported by high Mo 263 concentrations $(25-663 \mathrm{ppm}$; average $=138 \mathrm{ppm})$ and $U$ concentrations $(5-97 \mathrm{ppm}$; average $=22$ 264 ppm) in the Member IV ORM (Tribovillard et al., 2006; Scott and Lyons, 2012).

To further establish local depositional conditions in the Nanhua Basin during Member IV 266 time, we compared the enrichment factors (EFs) of Mo and U relative to average upper crust. 267 The EF is calculated as follows (Tribovillard et al., 2006):

$$
\mathrm{EF}_{\text {element } \mathrm{X}}=(\mathrm{X} / \mathrm{Al})_{\text {sample }} /(\mathrm{X} / \mathrm{Al})_{\text {average upper crust }}
$$

269 Average upper crust concentrations are $\mathrm{Mo}=1.5 \mathrm{ppm}, \mathrm{U}=2.8 \mathrm{ppm}$, and $\mathrm{Al}=80,400 \mathrm{ppm}$ 270 (McLennan, 2001). High EF values for both Mo (35-512; average = 142) and U (5-52; average = 271 14) indicate a dominance of hydrogenous over detrital contributions of Mo and U to Member IV 272 ORM. The Mo/U ratios of Member IV ORM consistently exceed those of modern seawater (Fig. 273 3a). This observation is consistent with the occurrence of locally euxinic bottom waters, and 274 unrestricted exchange between the local depositional basin and the open ocean (Algeo and 275 Tribovillard, 2009). High $\mathrm{Mo} / \mathrm{U}$ ratios in ORM can also be caused by the operation of a 
276 particulate Fe-Mn oxyhydroxide shuttle in a weakly restricted basin (as in the modern Cariaco

277 Basin), which leads to more efficient removal of Mo from the water column to sediments

278 compared to U (Algeo and Tribovillard, 2009).

\subsection{Uranium and molybdenum isotope compositions}

The $\mathrm{U}$ and Mo isotope data were not corrected for detrital contributions because of the

282 dominance of hydrogenous over detrital $U$ and Mo in the Member IV ORM. Despite the

283 persistence of euxinic bottom waters at the studied localities, the stratigraphic trends of $\delta^{238} \mathrm{U}$ 284 and $\delta^{98}$ Mo are significantly different (Fig. 2), with no significant correlation between them (Fig. 285 3b). In the Jiulongwan outcrop section, a few samples (HND 30.35, HND 29.5, HND 28.85) at 286 the base of Member IV have the lowest $\delta^{98}$ Mo $\left(-1.3\right.$ to $-0.5 \%$ ) and highest $\delta^{238} \mathrm{U}(0.4-0.5 \%$ ). 287 The rest of Member IV in the Jiulongwan section has uniform $\delta^{238} U(0.2-0.4 \%$ ) except for one 288 outlier near the top of the section (sample $\mathrm{HN}-23=-0.4 \%$ ). In contrast, the Mo isotope data 289 show a more complex pattern. The exceptionally low $\delta^{98}$ Mo at the base gives way upsection to $290 \delta^{98}$ Mo values between $-0.4 \%$ and $+0.4 \%$. This trend is followed up section by an excursion to 291 high $\delta^{98} \mathrm{Mo}$ (up to $2.0 \%$ ) near the top of Member IV. A return to low $\delta^{98}$ Mo values marks the 292 top of Member IV.

293 Stratigraphic trends in the Site 1 drill core section are similar to the Jiulongwan section 294 except for the absence of exceptionally low $\delta^{98}$ Mo and exceptionally high $\delta^{238} \mathrm{U}$ at the base of 295 Member IV. Hence, these few unusual isotopic signatures at the base of the Jiulongwan section 296 are possible post-depositional artifacts (e.g., modification by surficial fluids concentrated along 297 the Member III-IV contact) and are not considered further. In the Site 1 drill core, there is 298 minimal variation in $\delta^{238} \mathrm{U}(0.1-0.3 \%$ ) except for one outlier at the top of the section (sample 
40-4-of-12 =-0.13\%o). The $\delta^{98}$ Mo of lower Member IV ranges between $-0.5 \%$ and $+0.2 \%$. As in the Jiulongwan section, there is an excursion to high $\delta^{98} \mathrm{Mo}$ (up to $1.7 \%$ ) near the top of Member IV, which is followed by a return to lower $\delta^{98}$ Mo.

Hence, there are two major observations from the isotopic data: (1) dominantly uniform $\delta^{238} \mathrm{U}$ throughout most of Member IV (average $\delta^{238} \mathrm{U}=0.24 \pm 0.16 \%$, 2SD, 34 out of 39 samples; excluding HN-23, HND 30.35, HND 29.5, HND 28.85, and 40-4-of-12) and (2) a

prevalence of $\delta^{98}$ Mo values near $0 \%$ in Member IV except for an excursion to high $\delta^{98}$ Mo (1.7$2.0 \%$ ) near the top of both sections.

\subsection{Uranium isotopes: evidence for widespread ocean oxygenation at ca. 560-551 Ma}

Recent advances in our understanding of the modern marine $\mathrm{U}$ isotope budget have led to the application of $\mathrm{U}$ isotope data from ORM and carbonates as a paleoredox proxy (Weyer et al., 2008; Montoya-Pino et al., 2010; Brennecka et al., 2011a; Asael et al., 2013; Kendall et al., 2013; Andersen et al., 2014; Dahl et al., 2014). In oxygenated seawater, uranium exists as dissolved U(VI), primarily as the uranyl carbonate anion $\left(\mathrm{UO}_{2}\left[\mathrm{CO}_{3}\right]_{3}{ }^{4-}\right.$; Langmuir, 1978), and has a conservative distribution in the oceans with a residence time of $\sim 400-500 \mathrm{kyr}$ (Ku et al., 1977; Dunk et al., 2002). The single major source of $U$ to the oceans is oxidative mobilization of $\mathrm{U}$ from the upper continental crust and transport of dissolved $\mathrm{U}(\mathrm{VI})$ to the oceans via rivers (Dunk et al., 2002). In contrast, there are multiple marine sinks for U. Biogenic carbonates, sediments deposited beneath anoxic bottom waters, and sediments deposited beneath weakly oxygenated bottom waters are major sinks. Minor sinks include sediments deposited beneath 
322 well-oxygenated bottom waters and the hydrothermal alteration of oceanic crust (Morford and 323 Emerson, 1999; Dunk et al., 2002; Partin et al., 2013).

In anoxic basins, $\mathrm{U}$ is primarily removed below the sediment water-interface rather than

325 in the water column (Anderson et al., 1989; Barnes and Cochran, 1990). Uranium can be

326 precipitated from sediment pore waters as $\mathrm{UO}_{2}$ or adsorbed to organic matter following the 327 reduction of dissolved $\mathrm{U}(\mathrm{VI})$ to $\mathrm{U}(\mathrm{IV})$ at the depth of microbial $\mathrm{Fe}^{3+}$ and $\mathrm{SO}_{4}{ }^{2-}$ reduction (see 328 recent reviews on U marine geochemistry by Algeo and Tribovillard, 2009; Asael et al., 2013; 329 Partin et al., 2013). The reduction and removal of $U$ to the euxinic sediments of the deep Black 330 Sea is accompanied by a large volume-dependent equilibrium isotope fractionation that favors 331 the removal of heavier U isotopes from the water column (Schauble, 2006; Weyer et al., 2008; 332 Montoya-Pino et al., 2010; Andersen et al., 2014). Taking the offset between the average $\delta^{238} \mathrm{U}$ 333 of recent Unit I organic-rich sediments deposited from strongly euxinic waters at water depths of $334>2000 \mathrm{~m}(0.02 \pm 0.12 \%)$ and modern seawater $(-0.40 \pm 0.03 \%)$, the magnitude of isotope 335 fractionation is $\sim 0.4 \%$ (Weyer et al., 2008; Andersen et al., 2014). A similar offset was 336 determined between Unit I sediments and seawater at a water depth of $418 \mathrm{~m}$ (Weyer et al., 337 2008; Montoya-Pino et al., 2010). Given the restricted setting of the Black Sea, with 40\% U 338 depletion in the deep euxinic water column (Anderson et al., 1989), the observed offset between 339 Unit I sediments and seawater is only a minimum for open ocean settings. Using mass balance 340 modeling, Andersen et al. (2014) suggest that in an open ocean setting characterized by strong U 341 recharge to locally euxinic bottom waters and $U$ removal from solution below the sediment342 water interface, the $\mathrm{U}$ isotope fractionation between euxinic sediments and modern seawater will 343 be $\sim 0.6 \%$, which corresponds to a euxinic sediment $\delta^{238} \mathrm{U}$ of $\sim 0.2 \%$. 
In contrast to the anoxic sink, the other marine sinks are associated with small $\mathrm{U}$ isotope

345 fractionations. Peruvian continental margin sediments underlying weakly oxygenated waters

346 have an average $\delta^{238} \mathrm{U}$ of $-0.28 \pm 0.19 \%$, which is only $\sim 0.1 \%$ higher than seawater (Weyer et

347 al., 2008). The surface layers of Fe-Mn crusts in sediments underlying well-oxygenated bottom

348 waters $\left(-0.65 \pm 0.05 \%\right.$ ) show an opposite sense of isotope fractionation and have $\delta^{238} \mathrm{U}$ that is

$349 \sim 0.24 \%$ lower than seawater (Weyer et al., 2008; Brennecka et al., 2011b; Goto et al., 2014).

350 The $\mathrm{U}$ isotope fractionation accompanying hydrothermal alteration of oceanic crust may be

351 minimal if fresh and altered basalts typically have similar $\delta^{238} \mathrm{U}$ (Noordmann et al., 2010, 2011).

352 Primary biological and abiological carbonate precipitates show negligible offset from seawater

353 (Stirling et al., 2007; Weyer et al., 2008; Romaniello et al., 2013; Andersen et al., 2014). An

354 exception is shallow-water carbonate sediments containing dissolved sulfide in pore waters,

355 which can have $\delta^{238} \mathrm{U}$ values of 0.2-0.4 \%o higher compared to seawater (Romaniello et al., 356 2013).

357 Well-oxygenated bottom waters dominate the modern ocean. Because the expression of $358 \mathrm{U}$ isotope fractionation in oxygenated sediments is small, and the areal extent of weakly 359 oxygenated to anoxic bottom waters is limited, the $\delta^{238} \mathrm{U}$ of seawater is only slightly lower 360 compared to riverine inputs ( -0.3 to $0.0 \%$; Stirling et al., 2007; Noordmann et al., 2010, 2011).

361 In contrast, at times of expanded ocean anoxia, seawater $\delta^{238} U$ will be lower because of 362 extensive preferential removal of isotopically heavy $U$ isotopes to euxinic sediments (Weyer et 363 al., 2008; Montoya-Pino et al., 2010; Brennecka et al., 2011a). Hence, expanded ocean anoxia 364 should cause the $\delta^{238} \mathrm{U}$ of ancient euxinic ORM deposited in an open ocean euxinic setting to be 365 lower than $\sim 0.2 \%$ (Andersen et al., 2014). 

most Member IV ORM as evidence for widespread ocean oxygenation ca. 560-551 Myr ago. The 368 average $\delta^{238} \mathrm{U}$ value from Member IV is similar to the predicted $\delta^{238} \mathrm{U}$ for a hypothetical modern 369 euxinic sediment deposited in an unrestricted ocean basin. High Mo/U and Mo/TOC ratios for 370 Member IV ORM indicate that water exchange between the local depositional environment and 371 the open ocean was not severely restricted (Algeo and Lyons, 2006; Algeo and Tribovillard, 372 2009). The average Mo/TOC ratio of $23 \mathrm{ppm} / \mathrm{wt} \%$ for Member IV ORM (excluding the three 373 samples from the base of the Jiulongwan section) is similar to the average of $25 \mathrm{ppm} / \mathrm{wt} \%$ for the 374 weakly restricted Cariaco Basin (Algeo and Lyons, 2006). Hence, we suggest that the U isotope 375 fractionation between the Member IV euxinic sediments and global seawater was close to $0.6 \%$, 376 thus implying a late Ediacaran seawater $\delta^{238} U$ that was near the modern seawater value of $3770.4 \%$. Our interpretation assumes that riverine $\delta^{238} U$ during late Ediacaran time was broadly 378 similar to modern values of -0.3 to $0.0 \%$. However, Ediacaran rivers may have lower $\delta^{238} U$ 379 compared to modern rivers because Precambrian ORM with both high U concentrations and high $380 \delta^{238} \mathrm{U}$, a signature of well-oxygenated oceans, were probably less available for weathering (Partin 381 et al., 2013). A lower riverine $\delta^{238} \mathrm{U}$ implies that the seawater $\delta^{238} \mathrm{U}$ of a well-oxygenated 382 Ediacaran ocean was lower than modern seawater. Hence, the high average $\delta^{238} U$ of euxinic 383 Member IV ORM suggests extensive ocean oxygenation on a scale similar to or even greater 384 than today.

385 Our interpretation is consistent with high Mo concentrations in Member IV ORM, which 386 point to a high seawater Mo inventory in well-oxygenated oceans (Scott et al., 2008), and Fe 387 speciation evidence for locally oxygenated deep waters in some late Ediacaran ocean basins 
388 (Canfield et al., 2008; Johnston et al., 2012). Solitary low $\delta^{238} U$ values at the top of both sections may suggest a transient episode of expanded ocean anoxia during Member IV time.

The development of locally anoxic basins in continental margin environments is not precluded by our data and thus is not incompatible with geochemical evidence for local anoxia in 392 some late Ediacaran sedimentary basins (e.g., Canfield et al., 2008; Frei et al., 2013; Johnston et al., 2013). However, our data do indicate that anoxia was comparatively minor relative to ocean oxygenation at ca. 560-551 Ma. Our interpretations are based on the concentration and isotopic 395 composition of redox-sensitive trace metals (Mo, U) with long oceanic residence times (400-500 kyr). These geochemical tools, when applied to euxinic ORM, are more favorable for 397 constraining the global extent of ocean oxygenation and anoxia (Arnold et al., 2004; Weyer et al., 2008) compared to elements with short oceanic residence times.

Extensive ocean oxygenation ca. 560-551 Myr ago is coincident with the later stages of 400 the Shuram negative carbon isotope excursion (Fig. 4). In South China, the onset of the Shuram excursion occurs in Member III and ends at the Doushantuo-Dengying transition (Jiang et al., 2007; Zhou and Xiao, 2007; Zhu et al., 2007; McFadden et al., 2008; Sawaki et al., 2010; Tahata

404 widespread ocean oxygenation occurred during the entirety of the Shuram excursion. Hence, we 405 consider it beyond the scope of this paper to delve into the debate surrounding the origin of the 406 Shuram excursion (Grotzinger et al., 2011).

\subsection{Molybdenum isotopes: Constraints on global and local ocean redox conditions}

Molybdenum is oxidatively mobilized from the upper continental crust beneath an 
$411 \mathrm{MoO}_{4}{ }^{2-}$ (molybdate). Molybdenum behaves conservatively in oxygenated seawater and thus

412 accumulates in the oceans, leading to a long oceanic residence time of $\sim 440 \mathrm{kyr}$ (Miller et al.,

413 2011). Upon encountering sulfidic conditions in the water column or sediment pore fluids,

$414 \mathrm{MoO}_{4}{ }^{2-}$ is converted to $\mathrm{MoO}_{4-\mathrm{x}} \mathrm{S}_{\mathrm{x}}{ }^{2-}$ (thiomolybdate) (Helz et al., 1996; Erickson and Helz, 2000)

415 and then, at least in some settings, to reactive Mo-polysulfide species (Dahl et al., 2013). These

416 species are then scavenged by Fe sulfide minerals (Helz et al., 1996, 2004) and organic particles

417 (Helz et al., 1996; Tribovillard et al., 2004; Chappaz et al., 2014) or undergo equilibrium

418 precipitation as a $\mathrm{Fe}(\mathrm{II})-\mathrm{Mo}(\mathrm{VI})$ sulfide mineral (Helz et al., 2011), thus removing Mo to 419 sediments.

Where marine bottom waters become highly sulfidic ("strongly euxinic"; $\left[\mathrm{H}_{2} \mathrm{~S}\right]_{\mathrm{aq}}>11$

$421 \mu \mathrm{M}$ ), the quantitative conversion of $\mathrm{MoO}_{4}{ }^{2-}$ to $\mathrm{MoS}_{4}{ }^{2-}$ (tetrathiomolybdate) and its removal from

422 bottom waters can lead to the preservation of seawater $\delta^{98}$ Mo in sediments (Barling et al., 2001;

423 Arnold et al., 2004; Neubert et al., 2008). Doubts have been raised as to whether quantitative Mo

424 removal is characteristic of highly sulfidic marine basins (Helz et al., 2011). However, a small

425 isotopic offset between dissolved $\mathrm{MoS}_{4}{ }^{2-}$ and authigenic solid Mo ( $\Delta^{98} \mathrm{Mo} \sim 0.5 \pm 0.3 \%$; Nägler

426 et al., 2011) suggests the $\delta^{98}$ Mo of strongly euxinic sediments will closely approximate seawater

427 even if Mo removal from bottom waters is not quantitative. The long seawater Mo residence time

428 means that the $\delta^{98}$ Mo of strongly euxinic sediments at a single locality, including basins with

429 semi-restricted access to the open ocean, can stand as a proxy for global seawater, as shown for

430 the modern Black Sea (Barling et al., 2001; Arnold et al., 2004; Neubert et al., 2008).

431

Seawater $\delta^{98} \mathrm{Mo}$ represents an ocean redox proxy because it records the relative

432 proportion of Mo buried in marine sediments deposited beneath $\mathrm{O}_{2}$-rich and $\mathrm{O}_{2}$-poor waters.

433 Global seawater today is enriched in heavy Mo isotopes $\left(\delta^{98} \mathrm{Mo}=2.34 \pm 0.10 \%\right.$; Barling et al., 
434 2001; Siebert et al., 2003; Nakagawa et al., 2012; Nägler et al., 2014) relative to oceanic inputs 435 (dominated by rivers, average $\delta^{98} \mathrm{Mo} \sim 0.7 \%$; Archer and Vance, 2008). The extent of this 436 enrichment results largely from the preferential adsorption of light Mo isotopes in seawater onto 437 Mn oxides in sediments beneath oxygenated waters. The isotope fractionation during this process 438 is large ( 3\%o; Barling et al., 2001; Siebert et al., 2003, Barling and Anbar, 2004; Wasylenki et 439 al., 2008; Poulson Brucker et al., 2009). In contrast, isotope fractionation is often smaller 440 (typically $\leq 1 \%)$ during Mo burial in low- $\mathrm{O}_{2}(<10 \mu \mathrm{M})$ and anoxic marine environments where $441 \mathrm{H}_{2} \mathrm{~S}$ is present in pore and/or bottom waters (Barling et al., 2001; Arnold et al., 2004; Poulson et 442 al., 2006; Siebert et al., 2006; Neubert et al., 2008; Poulson Brucker et al., 2009). A notable 443 exception is weakly euxinic environments $\left(\left[\mathrm{H}_{2} \mathrm{~S}\right]_{\mathrm{aq}}<11 \mu \mathrm{M}\right)$ where sediments have $\delta^{98}$ Mo that is 444 up to $3.0 \%$ lower than seawater because of the incomplete conversion of molybdate to 445 tetrathiomolybdate and the preservation of Mo isotope fractionation during the formation of 446 intermediate thiomolybdate complexes (Arnold et al., 2004, 2012; Neubert et al., 2008; Dahl et 447 al., 2010a; Nägler et al., 2011; Azrieli-Tal et al., 2014). In continental margin environments 448 where bottom waters are mildly oxygenated (e.g., 10-35 $\mu \mathrm{M}$ ) and sediments are characterized by 449 active Fe-Mn oxide recycling above a deeper zone of dissolved sulfide, sediments have $\delta^{98} \mathrm{Mo}$ 450 that is intermediate between the well-oxygenated and strongly euxinic end-members (Siebert et 451 al., 2006; Poulson Brucker et al., 2009; Goldberg et al., 2012). The general picture that emerges 452 is that high seawater $\delta^{98}$ Mo reflects well-oxygenated oceans whereas low seawater $\delta^{98}$ Mo points 453 to extensive ocean anoxia, specifically a greater extent of strongly euxinic waters because it is in 454 such environments that Mo isotope fractionation between seawater and sediment is smallest. In 455 this way, the $\delta^{98}$ Mo of ancient seawater, as inferred from euxinic ORM, can be used to elucidate 
456 past global ocean redox conditions (e.g., Arnold et al., 2004; Dahl et al., 2010b; Kendall et al., 457 2011).

High $\delta^{98}$ Mo values (1.7-2.0\%) near the top of Member IV in both sections approach the modern seawater value of $2.3 \%$, which points to widespread oxygenation of the oceans just prior to $551 \mathrm{Ma}$ (Fig. 1). The highest $\delta^{98} \mathrm{Mo}$ in Member IV represents a minimum value for seawater 461 because of the possibility of isotopic fractionation between dissolved $\mathrm{MoS}_{4}{ }^{2-}$ and authigenic solid 462 Mo, which results in preferential removal of light Mo isotopes to sediments.

Seawater $\delta^{98}$ Mo is determined by the isotopic composition of inputs to the ocean and the 464 relative proportion of Mo buried into sediments of different redox character. The $\delta^{98}$ Mo of the 465 upper continental crust and riverine inputs is suggested to be broadly uniform during the past 2.7 466 Ga because no correlation exists between $\delta^{98}$ Mo and age for molybdenites, a major source of 467 oceanic Mo (Hannah et al., 2007). Nevertheless, Ediacaran rivers could have had lower $\delta^{98}$ Mo 468 than modern rivers because ORM with both high Mo concentrations and high $\delta^{98}$ Mo, indicative 469 of well-oxygenated conditions, were probably less available for weathering compared to today 470 (see section 5.3). Hence, an Ediacaran seawater $\delta^{98} \mathrm{Mo}$ of $\geq 2.0 \%$ suggests that the ratio of 471 dissolved Mo buried in mildly/strongly oxygenated versus low- $\mathrm{O}_{2}$ /anoxic marine environments 472 was comparable to or higher than that observed in today's predominantly oxygenated oceans.

473 In the isotopically heavy part of Member IV, the Mo/TOC ratios, which scale with Mo 474 concentrations in sulfidic bottom waters (Algeo and Lyons, 2006), reach 32-34 ppm/wt\%. These 475 ratios are similar to those of Phanerozoic euxinic ORM, reflecting enrichment under a large 476 dissolved Mo inventory and an appreciable extent of deep-ocean oxygenation (Scott et al., 2008;

477 Dahl et al., 2011; Dickson and Cohen, 2012; Sahoo et al., 2012; Reinhard et al., 2013). High 
$478 \delta^{98}$ Mo signatures together with high Mo/TOC provide a compelling case for widespread ocean 479 oxygenation.

Alternative scenarios to explain the combination of high $\delta^{98} \mathrm{Mo}$ and high Mo/TOC are unlikely. Large isotopic offsets of up to $\sim 3 \%$ lower than seawater are observed in modern Black

482 Sea sediments deposited beneath weakly euxinic waters near the chemocline $\left(\left[\mathrm{H}_{2} \mathrm{~S}\right]_{\mathrm{aq}}<11 \mu \mathrm{M}\right.$;

483 Neubert et al., 2008). If weakly euxinic waters were widespread throughout the late Ediacaran 484 oceans and such environments were typically characterized by a Mo isotope fractionation of $485 \sim 3 \%$ between seawater and ORM, then the seawater $\delta^{98}$ Mo could have been driven to high 486 values. However, this scenario is challenged by the well-known observation that Mo burial 487 fluxes to sediments are $\sim 2-3$ orders of magnitude higher in the presence of $\mathrm{H}_{2} \mathrm{~S}$ relative to $\mathrm{O}_{2}$, 488 even when dissolved $\mathrm{H}_{2} \mathrm{~S}$ in bottom waters is low (because sulfide is also present in sediment 489 pore waters; Scott et al., 2008; Poulson Brucker et al., 2009). The consequence of these high 490 burial rates is that the oceanic Mo inventory is sensitive to small changes in the extent of seafloor 491 covered by euxinic waters (Arnold et al., 2004). Recent modeling of the oceanic Mo inventory 492 and isotope mass balance demonstrates that if euxinia expanded to cover only $1 \%$ of the ocean 493 floor (compared to $<0.1 \%$ today), then the seawater Mo concentration would be less than one494 third the modern value, and the Mo abundances and Mo/TOC ratios of euxinic ORM would be 495 low (Scott et al., 2008; Dahl et al., 2011; Sahoo et al., 2012; Reinhard et al., 2013). Hence, 496 widespread weakly euxinic oceans will not generate both high Mo/TOC and high $\delta^{98}$ Mo in 497 ORM.

Interpretation of the Mo isotope data from the stratigraphically underlying and overlying

499 ORM in Member IV is less straightforward. At face value, the low $\delta^{98}$ Mo (typically $<0.8 \%$ ) of 500 these ORM suggests that seawater was isotopically light and hence that extensive Mo removal 
501 occurred beneath anoxic (and especially euxinic) water masses. However, this interpretation 502 conflicts with the high $\delta^{238} \mathrm{U}$ and high Mo/TOC that point to extensive oxygenation (this study; 503 Scott et al., 2008). Furthermore, some of these $\delta^{98}$ Mo values are appreciably lower than the 504 modern oceanic input $(\sim 0.7 \%)$. There is no known sink that can preferentially remove heavy Mo 505 isotopes from seawater, so seawater $\delta^{98}$ Mo is unlikely to be lower than the oceanic input.

On this basis, we infer that the low $\delta^{98}$ Mo values are fractionated from coeval seawater.

507 Sedimentary Fe speciation data point to persistently euxinic waters at the studied localities but do 508 not reveal if bottom water sulfide concentrations were high enough for quantitative $\mathrm{MoS}_{4}{ }^{2-}$ 509 formation and the capture of seawater-like $\delta^{98} \mathrm{Mo}$ in sediments. Following the Black Sea and 510 Mediterranean examples (Neubert et al., 2008; Arnold et al., 2012; Azrieli-Tal et al., 2014), the 511 lower $\delta^{98}$ Mo in Member IV ORM may record local deposition from weakly sulfidic waters and 512 the associated expression of Mo isotope fractionation during formation of intermediate 513 thiomolybdate complexes. In contrast, the higher $\delta^{98}$ Mo points to more intensely sulfidic local 514 conditions. The high Mo/U ratios of Member IV ORM consistently exceed the modern seawater 515 value, indicating that Mo was more efficiently transferred to the sediments compared to U (cf. 516 Algeo and Tribovillard, 2009). Hence, it is possible that the prevalence of lower $\delta^{98}$ Mo reflects 517 the operation of a particulate Fe-Mn oxyhydroxide shuttle analogous to that observed in the 518 weakly euxinic Cariaco Basin (Algeo and Tribovillard, 2009). The Fe-Mn oxyhydroxide 519 particles form at the chemocline where upwelling $\mathrm{Fe}^{2+}$ and $\mathrm{Mn}^{2+}$ comes into contact with 520 oxygenated waters. These particles will preferentially adsorb the lighter isotopes of Mo while 521 sinking through the water column. Reductive dissolution of Fe-Mn oxyhydroxide particles below 522 the sediment-water interface releases Mo, which can then be sequestered by Fe sulfide minerals 523 and organic particles, thus preserving a low $\delta^{98}$ Mo signature in sulfidic sediments (Herrmann et 
524 al., 2012; Scholz et al., 2013). In both sections, the samples with highest $\delta^{98}$ Mo have among the 525 lowest Mo/U ratios (see Fig. 3a), suggesting a decreased shuttle effect, along with increased 526 bottom water sulfide concentrations, enabled better capture of seawater $\delta^{98}$ Mo in these samples.

\subsection{Temporal trends in ocean oxygenation: the molybdenum isotope perspective}

To explore the relevance of our data within a broader temporal context, we compiled $530 \delta^{98} \mathrm{Mo}$ and associated Mo/TOC data from ORM deposited since the end of the Great Oxidation 531 Event (Fig. 4; inadequate $U$ isotope data exist for this purpose). We have recalculated the

532 literature $\delta^{98}$ Mo values relative to NIST SRM 3134 as $\delta^{98} \mathrm{Mo}=\left[\left({ }^{98 / 95} \mathrm{Mo}_{\text {sample }} /\left({ }^{98 / 95} \mathrm{Mo}_{\text {standard }} *\right.\right.\right.$ 0.99975) -1$] \times 1000$, following Nägler et al. (2014) by using the conversion values in Goldberg 534 et al. (2013). Our compilation, updated from Dahl et al. (2010b), includes our new data from 535 Member IV plus new data from the 640.7 \pm 4.7 Ma Black River Dolomite (Kendall et al., 2009b; 536 the Black River Dolomite is described in Appendix A and the data are reported in Table A.1). 537 The compilation specifically targeted ORM deposited beneath euxinic bottom waters as defined 538 by sedimentary Fe speciation (including degree-of-pyritization; Lyons and Severmann, 2006; 539 Scott et al., 2008) and included intervals containing ORM with Mo contents that are sufficiently 540 high to suggest euxinic conditions (Scott and Lyons, 2012). Although ORM deposited from 541 strongly euxinic bottom waters are most likely to capture a seawater-like $\delta^{98}$ Mo signature, 542 straightforward interpretation of the record is complicated by the likelihood that the $\delta^{98}$ Mo of 543 ORM deposited from weakly euxinic waters will be offset significantly to values lower than 544 those of seawater (as was observed for most Member IV samples). Hence, we use the highest $545 \delta^{98} \mathrm{Mo}$ from each interval as the most conservative estimate of coeval seawater because the 
546 highest $\delta^{98} \mathrm{Mo}$ in an interval could still be fractionated from seawater (Dahl et al., 2010b; 547 Dickson et al., 2014).

An interval of low $\delta^{98} \mathrm{Mo}$ and moderate Mo/TOC between $2050 \mathrm{Ma}$ and $640 \mathrm{Ma}$ points to 549 a generally moderate-sized oceanic Mo reservoir that reflects a combination of pervasive 550 oxidative weathering and redox-stratified oceans (oxic surface waters, euxinic waters at mid551 depths along productive ocean margins, and ferruginous deep waters; Arnold et al., 2004; Scott 552 et al., 2008; Kendall et al., 2009a, 2011; Dahl et al., 2010b, 2011; Planavsky et al., 2011; Poulton 553 and Canfield, 2011; Lyons et al., 2014). Elemental and isotopic mass balance models indicate 554 that the oceanic Mo reservoir probably stayed below 20\% of modern levels because of 555 pronounced Mo burial in sulfidic marine environments (Scott et al., 2008; Dahl et al., 2011; 556 Reinhard et al., 2013). Our new Mo data from the Black River Dolomite suggests that a similar 557 redox character prevailed at ca. $640 \mathrm{Ma}$, consistent with moderate Mo/TOC in ca. $660 \mathrm{Ma}$ 558 euxinic ORM from the lower part of the Datangpo Formation, South China (Li et al., 2012).

559 In contrast, Baldwin et al. (2013) infer a higher $\delta^{98}$ Mo of $\sim 1.8 \%$ for middle Cryogenian 560 seawater based on analyses of jasper beds from the dropstone-bearing (syn-glacial) Rapitan iron 561 formation (NW Canada). This value was calculated assuming Mo isotope fractionation during 562 adsorption to hematite. An alternative to this local-scale interpretation is that high seawater $563 \delta^{98}$ Mo was generated globally by preferential removal of isotopically light Mo from a small 564 oceanic Mo reservoir to abundant Fe oxyhydr(oxides). Under icehouse conditions where the 565 oceans are stagnant and predominantly anoxic (thus Mo-poor) beneath widespread ice cover 566 (with low sulfur inputs), Fe oxyhydr(oxides) would likely precipitate as a result of $\mathrm{Fe}^{2+}$ oxidation 567 via oxygenic photosynthesis beneath thin ice cover or via photoferrotrophy (Kirschvink, 1992; 568 Canfield and Raiswell, 1999; Hoffman and Schrag, 2002). As another (non-glacial) example 
569 involving extensive ocean anoxia, preferential removal of isotopically light Mo from a small

570 oceanic Mo inventory to Fe oxyhydr(oxides) was suggested to account for high $\delta^{98}$ Mo in late

571 Archean euxinic ORM deposited before the Great Oxidation Event (Duan et al., 2010; Czaja et 572 al., 2012).

High Mo/TOC ratios from ORM of lower Member II near the base of the Doushantuo

574 Formation indicate extensive ocean oxygenation at ca. $632 \mathrm{Ma}$ (Sahoo et al., 2012). Otherwise, 575 geochemical data from early and middle Ediacaran sedimentary successions are consistent with 576 less oxygenated conditions, except following the ca. 580 Ma Gaskiers glaciation and at ca. 560577551 Ma (Canfield et al., 2007, 2008; McFadden et al., 2008; Li et al., 2010; Johnston et al., 2012; 578 Och and Shields-Zhou, 2012). Future work is required to determine if additional episodes of 579 extensive ocean oxygenation also took place during early and middle Neoproterozoic time. Late Ediacaran ocean oxygenation is roughly coincident with key steps in the radiation of 581 animals. Weakly calcified tubular metazoans (e.g., Cloudina) and their predators appeared before $582548.8 \pm 1$ Ma (Bengston and Zhao, 1992; Grotzinger et al., 1995; Warren et al., 2012). 583 Macroscopic motile bilaterians (e.g., Kimberella) and their trace fossils appear in the rock record 584 by $555.3 \pm 0.3 \mathrm{Ma}$ and $585 \pm 3 \mathrm{Ma}$, respectively (Martin et al., 2000; Fedonkin et al., 2007; Liu 585 et al., 2010; Pecoits et al., 2012; Rogov et al., 2012). Regionally stable ocean oxygenation 586 following the Gaskiers glaciation is temporally associated with the appearance of soft-bodied 587 Ediacaran macroscopic fauna (Canfield et al., 2007; Narbonne et al., 2009; Xiao and Laflamme, 588 2009; Wilby et al., 2011; Johnston et al., 2012). However, surface ocean oxygen levels during 589 earlier Neoproterozoic time were not necessarily low enough to preclude the existence of small 590 bilaterians (Sperling et al., 2013a; Planavsky et al., 2014). Furthermore, ecological and genetic 591 factors were likely important driving forces for metazoan evolution (e.g., Butterfield, 2009; 
592 Erwin et al., 2011; Penny et al., 2014). Disentangling the relative importance of environmental, 593 ecological, and genetic factors is difficult given the current resolution of geochemical and 594 paleontological datasets. However, it is likely that the initial episodes of extensive ocean 595 oxygenation helped accelerate the radiation of Ediacaran metazoans in tandem with ecological 596 triggers, because more complex food webs and larger metazoans would be supported by higher 597 oxygen levels (Sperling et al., 2013b). High $\delta^{98}$ Mo and high Mo/TOC from early Cambrian 598 ORM (Wille et al., 2008) and high $\delta^{98}$ Mo from phosphorites (Wen et al., 2011) suggest at least 599 transient occurrences of widespread ocean oxygenation around the time of the Cambrian 600 Explosion.

A return to generally less oxygenated deep oceans with expanded sulfidic marine 602 environments (possibly triggered by a significant increase in bioturbation; Boyle et al., 2014) is 603 marked by lower $\delta^{98} \mathrm{Mo}$ and lower Mo/TOC at 520-440 Ma, except for one example of high $604 \delta^{98} \mathrm{Mo}$ in the late Ordovician (Dahl et al., 2010b; Zhou et al., 2012). This time interval includes 605 an episode of extreme $\mathrm{O}_{2}$ deficiency during the ca. 500 Ma Steptoean Positive Carbon Isotope 606 Excursion (SPICE) (Gill et al., 2011). Because the $\delta^{98} \mathrm{Mo}$ and Mo/TOC proxies are highly 607 sensitive to changes in the extent of water column euxinia over a small percentage of the 608 seafloor, it is difficult to infer the redox state of early Paleozoic deep oceans using Mo alone. A 609 return to Proterozoic-style ferruginous deep ocean conditions (Planavsky et al., 2011; Poulton 610 and Canfield, 2011) is not strictly required to explain the low $\delta^{98} \mathrm{Mo}$ and moderate $\mathrm{Mo} / \mathrm{TOC}$ at 611 520-440 Ma despite the similarities in Mo data with the ca. 2050-640 Ma interval. Compilations 612 of $\mathrm{Cr}$ and $\mathrm{U}$ concentrations in ORM suggest a first-order increase in the seawater inventory of 613 these metals in the early Paleozoic compared to the Precambrian (Reinhard et al., 2013; Partin et 614 al., 2013). The oceanic mass balances of $\mathrm{Cr}$ and $\mathrm{U}$ are less sensitive to water column euxinia 
615 compared to Mo. Taking this into account, the Mo data at 520-440 Ma can be interpreted as

616 reflecting mid-depth euxinic waters along productive ocean margins and weakly oxygenated

617 deep waters (cf. Dahl et al., 2010b).

618 High $\delta^{98} \mathrm{Mo}$ and generally high Mo/TOC in later Phanerozoic ORM indicates that 619 widespread and persistent ocean oxygenation was probably established by 390 Ma, possibly 620 coincident with the diversification of vascular land plants (Dahl et al., 2010b). Widespread ocean 621 oxygenation during younger Phanerozoic time may have been interrupted only by sporadic, brief 622 intervals of expanded oceanic anoxia during which the oceanic Mo inventory and seawater $623 \delta^{98}$ Mo became temporarily smaller and lower, respectively (e.g., the Mesozoic examples in Fig. 624 4; Pearce et al., 2008, 2010; Westermann et al., 2014). The picture that emerges is an Ediacaran 625 to early Paleozoic interval of fluctuating ocean redox conditions that bridges the transition from $626 \mathrm{O}_{2}$-deficient Proterozoic oceans to widely oxygenated later Phanerozoic oceans.

627 628

\section{CONCLUSIONS}

629

630

New U and Mo isotope data from Member IV ORM of the Doushantuo Formation point 631 to extensively oxygenated oceans during ca. 560-551 Ma, consistent with the previous 632 conclusion reached by Scott et al. (2008) on the basis of high Mo concentrations in Member IV. 633 The consistently high $\delta^{238} \mathrm{U}$ values throughout Member IV, when corrected for isotope 634 fractionation accompanying $U$ burial in ORM, point to high seawater $\delta^{238} \mathrm{U}$ at $560-551 \mathrm{Ma}$ and 635 hence a broadly similar oceanic redox character and oceanic $U$ isotope mass balance as today. 636 Most of the Mo isotope data in Member IV are probably fractionated from seawater, consistent 637 with deposition from local bottom waters that were weakly sulfidic $\left(\left[\mathrm{H}_{2} \mathrm{~S}\right]_{\mathrm{aq}}<11 \mu \mathrm{M}\right)$. High 
$638 \mathrm{Mo} / \mathrm{U}$ ratios also suggest the efficient transfer of isotopically light Mo to sediments by a local 639 particulate Fe-Mn oxyhydroxide shuttle. However, an instance of high seawater $\delta^{98}$ Mo paired 640 with high Mo/TOC occurs in the upper part of Member IV, again pointing to widespread ocean 641 oxygenation. A temporal compilation of $\delta^{98} \mathrm{Mo}$ and associated Mo/TOC reveals that ocean 642 oxygenation was probably not a linear process. It is likely that the late Neoproterozoic rise in 643 atmospheric $\mathrm{O}_{2}$ led to an Ediacaran-to-early-Phanerozoic interval of dynamic ocean redox 644 changes, which bridged the transition from predominantly $\mathrm{O}_{2}$-deficient Proterozoic oceans to 645 widely oxygenated later Phanerozoic oceans.

646

647 648 649 650 651

652 653 654 655 656

\section{A.1. Black River Dolomite samples}

658 manuscript.

\section{ACKNOWLEDGEMENTS}

This study was financially supported by the National Science Foundation, the NASA Astrobiology Institute, and the Agouron Institute. Support was provided to TWL by NSF-EAR and the NASA Exobiology and Astrobiology programs. BK is supported by a NSERC Discovery Grant (RGPIN-435930). Constructive comments by three anonymous reviewers improved the

\section{APPENDIX A}

The Western Tasmania Terrane is suggested to have formed part of the East Antarctic margin of the Australia-East Antarctica continental block during the Neoproterozoic before 
661 rifting away at ca. $580 \mathrm{Ma}$ (Direen and Crawford, 2003; Meffre et al., 2004; Berry et al., 2008).

662 In northwestern Tasmania, the ca. 740-542 Ma Togari Group begins locally with the coarse663 grained Forest Conglomerate, which in turn is overlain by $600 \mathrm{~m}$ of stromatolitic dolostones, 664 organic-rich chert and mudrock, and diamictite of the Black River Dolomite (Calver, 1998; 665 Calver and Walter, 2000). These lithologies record continental shelf deposition, with the organic666 rich units representing sedimentation in deeper-water environments. Overlying the Black River 667 Dolomite are fine-grained mudrocks, volcaniclastic arenites, rhyodacite, diamictite, and tholeiitic 668 basalt of the $1 \mathrm{~km}$ thick Kannunah Subgroup, deposited in a rift setting (Calver et al., 2004). In 669 the Forest-1 core, the top of the Black River Dolomite is represented by $40 \mathrm{~m}$ of pyritic ORM 670 with subordinate carbonate (Calver and Walter, 2000). Samples of finely laminated pyritic ORM 671 were obtained from the lower part of this interval at ca. $828 \mathrm{~m}$ and $836 \mathrm{~m}$ depth in Forest-1. A 672 precise Re-Os depositional age of $640.7 \pm 4.7 \mathrm{Ma}(\mathrm{MSWD}=0.91)$ was obtained from the ORM 673 at $836 \mathrm{~m}$ (Kendall et al., 2009b). Molybdenum concentration and isotope data, sedimentary Fe 674 speciation analyses, and TOC data were obtained using the same methods described in section 3 675 (Analytical Methods). Data are presented in Table A.1.

676

677 678 679 680 681 682 683

\section{REFERENCES}

Algeo T. J. and Lyons T. W. (2006) Mo-total organic carbon covariation in modern anoxic marine environments: Implications for analysis of paleoredox and paleohydrographic conditions. Paleoceanogr. 21, PA1016.

Algeo T. J. and Tribovillard N. (2009) Environmental analysis of paleoceanographic systems based on molybdenum-uranium covariation. Chem. Geol. 268, 211-225. 
Andersen M. B., Romaniello S., Vance D., Little S. H., Herdman R. and Lyons T. W. (2014) A modern framework for the interpretation of ${ }^{238} U / 235 \mathrm{U}$ in studies of ancient ocean redox. Earth Planet. Sci. Lett. 400, 184-194.

Anderson R. F., Fleischer M. Q. and LeHuray A. P. (1989) Concentration, oxidation state, and particulate flux of uranium in the Black Sea. Geochim. Cosmochim. Acta 53, 2215-2224.

Anderson T. F. and Raiswell R. (2004) Sources and mechanisms for the enrichment of highly reactive iron in euxinic Black Sea sediments. Am. J. Sci. 304, 203-233.

Archer C. and Vance D. (2008) The isotopic signature of the global riverine molybdenum flux and anoxia in the ancient oceans. Nature Geosci. 1, 597-600.

Arnold G. L., Anbar A. D., Barling J. and Lyons T. W. (2004) Molybdenum isotope evidence for widespread anoxia in Mid-Proterozoic oceans. Science 304, 87-90.

Arnold G. L., Lyons T. W., Gordon G. W. and Anbar A. D. (2012) Extreme change in sulfide concentrations in the Black Sea during the Little Ice Age reconstructed using molybdenum isotopes. Geology 40, 595-598.

Asael D., Tissot F. L. H., Reinhard C. T., Rouxel O., Dauphas N., Lyons T. W., Ponzevera E., Liorzou C. and Chéron S. (2013) Coupled molybdenum, iron and uranium stable isotopes as oceanic paleoredox proxies during the Paleoproterozoic Shunga Event. Chem. Geol. 362, 193-210.

Azrieli-Tal I., Matthews A., Bar-Matthews M., Almogi-Labin A., Vance D., Archer C. and Teutsch N. (2014) Evidence from molybdenum and iron isotopes and molybdenumuranium covariation for sulphidic bottom waters during Eastern Mediterranean sapropel S1 formation. Earth Planet. Sci. Lett. 393, 231-242. 
Bailey J. V., Joye S. B., Kalanetra K. M., Flood B. E. and Corsetti F. A. (2007) Evidence of giant sulphur bacteria in Neoproterozoic phosphorites. Nature 445, 198-201.

Baldwin G. J., Nägler T. F., Greber N. D., Turner E. C. and Kamber B. S. (2013) Mo isotopic composition of the mid-Neoproterozoic ocean: An iron formation perspective. Precambr. Res. 230, 168-178.

Barling J. and Anbar A. D. (2004) Molybdenum isotope fractionation during adsorption by manganese oxides. Earth Planet. Sci. Lett. 217, 315-329.

Barling J. Arnold G. L. and Anbar A. D. (2001) Natural mass-dependent variations in the isotopic composition of molybdenum. Earth Planet. Sci. Lett. 193, 447-457.

Barnes C. E. and Cochran J. K. (1990) Uranium removal in oceanic sediments and the oceanic U balance. Earth Planet. Sci. Lett. 97, 94-101.

Bengtson S. and Zhao Y. (1992) Predatorial borings in late Precambrian mineralized exoskeletons. Science 257, 367-369.

Berry R. F., Steele D. A., and Meffre S. (2008) Proterozoic metamorphism in Tasmania: Implications for tectonic reconstructions. Precambr. Res. 166, 387-396.

Boyle R. A., Dahl T. W., Dale A. W., Shields-Zhou G. A., Zhu M., Brasier M. D., Canfield D. E. and Lenton T. M. (2014) Stabilization of the coupled oxygen and phosphorus cycles by the evolution of bioturbation. Nature Geosci. 7, 671-676.

Brennecka G. A., Herrmann A. D., Algeo T. J. and Anbar A. D. (2011a) Rapid expansion of ocean anoxia immediately before the end-Permian mass extinction. Proc. Natl. Acad. Sci. USA 108, 17631-17634. 
727 Brennecka G. A., Wasylenki L. E., Bargar J. R., Weyer S. and Anbar A. D. (2011b) Uranium

728

729

730

731

732

733

734

735

736

737

738

739

740

741

742

743

744

745

746

747 isotope fractionation during adsorption to Fe-Mn oxyhydroxides. Environ. Sci. Tech. 45, 1370-1375.

Butterfield N. J. (2009) Oxygen, animals and oceanic ventilation: an alternative view. Geobiol. $7,1-7$.

Calver C. R. (1998) Isotope stratigraphy of the Neoproterozoic Togari Group, Tasmania. Aust. J. Earth Sci. 45, 865-874.

Calver C. R. (2000) Isotope stratigraphy of the Ediacaran (Neoproterozoic III) of the Adelaide rift complex, Australia, and the overprint of water column stratification. Precambr. Res. 100, 121-150.

Calver C. R. and Walter M. R. (2000) The late Neoproterozoic Grassy Group of King Island, Tasmania: correlation and palaeogeographic significance. Precambr. Res. 100, 299-312.

Calver C. R., Black L. P., Everard J. L. and Seymour D. B. (2004) U-Pb zircon age constraints on late Neoproterozoic glaciation in Tasmania. Geology 32, 893-896.

Canfield D. E. and Raiswell R. (1999) The evolution of the sulfur cycle. Amer. J. Sci. 299, 697723.

Canfield D. E., Poulton S. W. and Narbonne G. M. (2007) Late-Neoproterozoic deep-ocean oxygenation and the rise of animal life. Science 315, 92-95.

Canfield D. E., Poulton S. W., Knoll A. H., Narbonne G. M., Ross G., Goldberg T. and Strauss H. (2008) Ferruginous conditions dominated later Neoproterozoic deep-water chemistry. Science 321, 949-952. 
Chappaz A., Lyons T. W., Gregory D. D., Reinhard C. T., Gill B. C., Li C. and Large R. R. (2014) Does pyrite act as an important host for molybdenum in modern and ancient euxinic sediments? Geochim. Cosmochim. Acta 126, 112-122.

Chen D. F., Dong W. Q., Zhu B. Q. and Chen X. P. (2004) Pb-Pb ages of Neoproterozoic Doushantuo phosphorites in South China: constraints on early metazoan evolution and glaciation events. Precambr. Res. 132, 123-132.

Chen L., Xiao S., Pang K., Zhou C. and Yuan X. (2014) Cell differentiation and germ-soma separation in Ediacaran animal embryo-like fossils. Nature 516, 238-241.

Chen Z., Bengtson S., Zhou C., Hua H. and Yue Z. (2008) Tube structure and original composition of Sinotubulites: Shelly fossils from the late Neoproterozoic in southern Shaanxi, China. Lethaia 41, 37-45.

Condon D., Zhu M., Bowring S., Wang W., Yang A. and Jin Y. (2005) U-Pb ages from the Neoproterozoic Doushantuo Formation, China. Science 308, 95-98.

Czaja A. D., Johnson C. M., Roden E. E., Beard B. L., Voegelin A. R., Nägler T. F., Beukes N. J. and Wille M. (2012) Evidence for free oxygen in the Neoarchean ocean based on coupled iron-molybdenum isotope fractionation. Geochim. Cosmochim. Acta 86, 118137.

Dahl T. W., Anbar A. D., Gordon G. W., Rosing M. T., Frei R. and Canfield D. E. (2010a) The behavior of molybdenum and its isotopes across the chemocline and in the sediments of sulfidic Lake Cadagno, Switzerland. Geochim. Cosmochim. Acta 74, 144-163.

Dahl T. W., Hammarlund E. U., Anbar A. D., Bond D. P. G., Gill B. C., Gordon G. W., Knoll A. H., Nielsen A. T., Schovsbo N. H. and Canfield D. E. (2010b) Devonian rise in 
atmospheric oxygen correlated to the radiations of terrestrial plants and large predatory fish: Proc. Natl. Acad. Sci. USA 107, 17911-17915.

Dahl T. W., Canfield D. E., Rosing M. T., Frei R. E., Gordon G. W., Knoll A. H. and Anbar A. D. (2011) Molybdenum evidence for expansive sulfidic water masses in 750 Ma oceans. Earth Planet. Sci. Lett. 311, 264-274.

Dahl T. W., Chappaz A., Fitts J. P. and Lyons T. W. (2013) Molybdenum reduction in a sulfidic lake: Evidence from X-ray absorption fine-structure spectroscopy and implications for the Mo paleoproxy. Geochim. Cosmochim. Acta 103, 213-231.

Dahl T. W., Boyle R. A., Canfield D. E., Connelly J. N., Gill B. C., Lenton T. M. and Bizzaro M. (2014) Uranium isotopes distinguish two geochemically distinct stages during the later Cambrian SPICE event. Earth Planet. Sci. Lett. 401, 313-326.

Dickson A. J. and Cohen A. S. (2012) A molybdenum isotope record of Eocene Thermal Maximum 2: Implications for global ocean redox during the early Eocene. Paleoceanogr. 27, PA3230.

Dickson A. J., Cohen A. S. and Coe A. L. (2012) Seawater oxygenation during the PaleoceneEocene Thermal Maximum. Geology 40, 639-642.

Dickson A. J., Cohen A. S. and Coe A. L. (2014) Continental margin molybdenum isotope signatures from the early Eocene. Earth Planet. Sci. Lett. 404, 389-395.

Direen N. G. and Crawford A. J. (2003) Fossil seaward-dipping reflector sequences preserved in southeastern Australia: a $600 \mathrm{Ma}$ volcanic passive margin in eastern Gondwanaland. $J$. Geol. Soc. London 160, 985-990. 
Duan Y., Anbar A. D., Arnold G. L., Lyons T. W., Gordon G. W. and Kendall B. (2010) Molybdenum isotope evidence for mild environmental oxygenation before the Great Oxidation Event. Geochim. Cosmochim. Acta 74, 6655-6668.

Dunk R. M., Mills R. A. and Jenkins W. J. (2002) A reevaluation of the oceanic uranium budget for the Holocene. Chem. Geol. 190, 45-67.

Erickson B. E. and Helz G. R. (2000) Molybdenum (VI) speciation in sulfidic waters: Stability and lability of thiomolybdates. Geochim. Cosmochim. Acta 64, 1149-1158.

Erwin D. H., Laflamme M., Tweedt S. M., Sperling E. A., Pisani D. and Peterson K. J. (2011) The Cambrian conundrum: Early divergence and later ecological success in the early history of animals. Science 334, 1091-1097.

Fan H., Zhu X., Wen H., Yan B., Li J., Feng L. (2014) Oxygenation of Ediacaran ocean recorded by iron isotopes. Geochim. Cosmochim. Acta 140, 80-94.

Fedonkin M. A., Simonetta A. and Ivantsov A. Y. (2007) New data on Kimberella, the Vendian mollusc-like organism (White Sea region, Russia): paleoecological and evolutionary implications. Geol. Soc. Lon. Spec. Publ. 286, 157-179.

Fike D. A., Grotzinger J. P., Pratt L. M. and Summons R. E. (2006) Oxidation of the Ediacaran ocean. Nature 444, 744-747.

Frei R., Gaucher C., Stolper D. and Canfield D. E. (2013) Fluctuations in late Neoproterozoic atmospheric oxidation - $\mathrm{Cr}$ isotope chemostratigraphy and iron speciation of the late Ediacaran lower Arroyo del Soldado Group (Uruguay). Gondwana Res. 23, 797-811.

Gill B. C., Lyons T. W., Young S. A., Kump L. R., Knoll A. H. and Saltzman M. R. (2011) Geochemical evidence for widespread euxinia in the later Cambrian ocean. Nature 469, 80-83. 
814 Goldberg T., Archer C., Vance D., Thamdrup B., McAnena A. and Poulton S. W. (2012)

815

816

817

818

819

820

821

822

823

824

825

826

827

828

829

830

831

832

833

834

835

Controls on Mo isotope fractionations in a Mn-rich anoxic marine sediment, Gullmar Fjord, Sweden. Chem. Geol. 296-297, 73-82.

Goldberg T., Gordon G., Izon G., Archer C., Pearce C. R., McManus J., Anbar A. D. and Rehkämper M. (2013) Resolution of inter-laboratory discrepancies in Mo isotope data: an intercalibration. J. Anal. At. Spectrom. 28, 724-735.

Gordon G. W., Lyons T. W., Arnold G. L., Roe J., Sageman B. B. and Anbar A. D. (2009) When do black shales tell molybdenum isotope tales? Geology 37, 535-538.

Goto K. T., Anbar A. D., Gordon G. W., Romaniello S. J., Shimoda G., Takaya Y., Tokumaru A., Nozaki T., Suzuki K., Machida S., Hanyu T. and Usui A. (2014) Uranium isotope systematics of ferromanganese crusts in the Pacific Ocean: Implications for the marine ${ }^{238} \mathrm{U} /{ }^{235} \mathrm{U}$ isotope system. Geochim. Cosmochim. Acta 146, 43-58.

Grotzinger J. P., Bowring S. A., Saylor B. Z. and Kaufman A. J. (1995) Biostratigraphic and geochronologic constraints on early animal evolution. Science 270, 598-604.

Grotzinger J. P., Fike D. A. and Fischer W. W. (2011) Enigmatic origin of the largest-known carbon isotope excursion in Earth's history. Nature Geosci. 4, 285-292.

Guan C., Zhou C., Wang W., Wan B., Yuan X. and Chen Z. (2014) Fluctuation of shelf basin redox conditions in the early Ediacaran: Evidence from Lantian Formation black shales in South China. Precambr. Res. 245, 1-12.

Hannah J. L., Stein H. J., Wieser M. E., de Laeter J. R. and Varner M. D. (2007) Molybdenum isotope variations in molybdenite: Vapor transport and Rayleigh fractionation of Mo. Geology 35, 703-706. 
Helz G. R., Miller C. V., Charnock J. M., Mosselmans J. F. W, Pattrick R. A. D, Garner C. D. and Vaughan D. J. (1996) Mechanism of molybdenum removal from the sea and its concentration in black shales: EXAFS evidence. Geochim. Cosmochim. Acta 60, 36313642.

Helz G. R., Vorlicek T. P. and Kahn M. D. (2004) Molybdenum scavenging by iron monosulfide. Environ. Sci. Tech. 38, 4263-4268.

Helz G. R., Bura-Nakić E., Mikac N. and Ciglenečki I. (2011) New model for molybdenum behavior in euxinic waters. Chem. Geol. 284, 323-332.

Herrmann A. D., Kendall B., Algeo T. J., Gordon G. W., Wasylenki L. E. and Anbar A. D. (2012) Anomalous molybdenum isotope trends in Upper Pennsylvanian euxinic facies: Significance for use of $\delta^{98} \mathrm{Mo}$ as a global marine redox proxy. Chem. Geol. 324-325, 8798.

Hoffman P. F. and Schrag D. P. (2002) The snowball Earth hypothesis: testing the limits of global change. Terra Nova 14, 129-155.

Huldtgren T., Cunningham J. A., Yin C., Stampanoni M., Marone F., Donoghue P. C. J and Bengtson S. (2011) Fossilized nuclei and germination structures identify Ediacaran “animal embryos” as encysting protists. Science 334, 1696-1699.

Jiang G., Sohl L. E. and Christie-Blick N. (2003) Neoproterozoic stratigraphic comparison of the Lesser Himalaya (India) and Yangtze block (South China): Paleogeographic implications. Geology 31, 917-920.

Jiang G., Kaufman A. J., Christie-Blick N., Zhang S. and Wu H. (2007) Carbon isotope variability across the Ediacaran Yangtze platform in South China: Implications for a large surface-to-deep ocean $\delta^{13} \mathrm{C}$ gradient. Earth Planet. Sci. Lett. 261, 303-320. 
Jiang G., Shi X., Zhang S., Wang Y. and Xiao S. (2011) Stratigraphy and paleogeography of the Ediacaran Doushantuo Formation (ca. 635-551 Ma) in South China. Gondwana Res. 19, 831-849.

Johnston D. T., Poulton S. W., Goldberg T., Sergeev V. N., Podkovyrov V., Vorob'eva N. G., Bekker A. and Knoll A. H. (2012) Late Ediacaran redox stability and metazoan evolution. Earth Planet. Sci. Lett. 335-336, 25-35.

Johnston D. T., Poulton S. W., Tosca N. J., O'Brien T., Halverson G. P., Schrag D. P. and Macdonald F. A. (2013) Searching for an oxygenation event in the fossiliferous Ediacaran of northwestern Canada. Chem. Geol. 362, 273-286.

Kaufman A. J., Jiang G., Christie-Blick N., Banerjee D. M. and Rai V. (2006) Stable isotope record of the terminal Neoproterozoic Krol platform in the Lesser Himalayas of northern India. Precambr. Res. 147, 156-185.

Kendall B., Creaser R. A., Gordon G. W. and Anbar A. D. (2009a) Re-Os and Mo isotope systematics of black shales from the Middle Proterozoic Velkerri and Wollogorang Formations, McArthur Basin, northern Australia. Geochim. Cosmochim. Acta 73, 25342558.

Kendall B., Creaser R. A., Calver C. R., Raub T. D. and Evans D. A. D. (2009b) Correlation of Sturtian diamictite successions in southern Australia and northwestern Tasmania by ReOs black shale geochronology and the ambiguity of "Sturtian"-type diamictite-cap carbonate pairs as chronostratigraphic marker horizons. Precambr. Res. 172, 301-310.

Kendall B., Gordon G. W., Poulton S. W. and Anbar A. D. (2011) Molybdenum isotope constraints on the extent of late Paleoproterozoic ocean euxinia. Earth Planet. Sci. Lett. 307, 450-460. 
882 Kendall B., Brennecka G. A., Weyer S. and Anbar A. D. (2013) Uranium isotope fractionation 883 suggests oxidative uranium mobilization at 2.50 Ga. Chem. Geol. 362, 105-114.

884 Kikumoto R., Tahata M., Nishizawa M., Sawaki Y., Maruyama S., Shu D., Han J., Komiya T., 885 886 887 888 889 890 891 892 893 894 895 Takai K. and Ueno Y. (2014) Nitrogen isotope chemostratigraphy of the Ediacaran and Early Cambrian platform sequence at Three Gorges, South China. Gondwana Res. 25,

7
1057-1069.

Kirschvink J. L. (1992) Late Proterozoic low-latitude global glaciation: the snowball Earth. In The Proterozoic Biosphere (eds. J. W. Schopf and C. Klein), pp. 51-52. Cambridge University Press.

Knoll A. H. (2011) The multiple origins of complex multicellularity. Ann. Rev. Earth Planet. Sci. 39, 217-239.

Knoll A. H. and Carroll S. B. (1999) Early animal evolution: Emerging views from comparative biology and geology. Science 284, 2129-2137.

Ku T. L., Knauss K. and Mathieu G. G. (1977) Uranium in the open ocean: concentration and isotopic composition. Deep Sea Res. 24, 1005-1017.

Langmuir D. (1978) Uranium solution-mineral equilibria at low temperatures with applications to sedimentary ore deposits. Geochim. Cosmochim. Acta 42, 547-569.

Le Guerroué E. (2010) Duration and synchroneity of the largest negative carbon isotope excursion on Earth: The Shuram/Wonoka anomaly. Compt. Rend. Geosci. 342, 204-214.

901 Lehmann B., Nägler T. F., Holland H. D., Wille M., Mao J., Pan J., Ma D. and Dulski P. (2007)

902 Highly metalliferous carbonaceous shale and Early Cambrian seawater. Geology 35, 403903 406. 
Lenton T. M., Boyle R. A., Poulton S. W., Shields-Zhou G. A. and Butterfield N. J. (2014) Coevolution of eukaryotes and ocean oxygenation in the Neoproterozoic Era. Nature Geosc. 7, 257-265.

Li C., Love G. D., Lyons T. W., Fike D. A., Sessions A. L. and Chu X. (2010) A stratified redox model for the Ediacaran ocean: Science 328, 80-83.

Li C., Love G. D., Lyons T. W., Scott C. T., Feng L., Huang J., Chang H., Zhang Q. and Chu X. (2012) Evidence for a redox stratified Cryogenian marine basin, Datangpo Formation, South China. Earth Planet. Sci. Lett. 331-332, 246-256.

Liu A. G., McIlroy D. and Brasier M. D. (2010) First evidence for locomotion in the Ediacara biota from the 565 Ma Mistaken Point Formation, Newfoundland. Geology 38, 123-126.

Lowenstein T. K., Kendall B. and Anbar A. D. (2014) Chapter 8.21 - The geologic history of seawater. In The Oceans and Marine Geochemistry, Treatise on Geochemistry 2nd Edition, vol. 8 (eds. H. D. Holland and K. K. Turekian), pp. 569-622. Elsevier.

Lyons T. W. and Severmann S. (2006) A critical look at iron paleoredox proxies: New insights from modern euxinic marine basins. Geochim. Cosmochim. Acta 70, 5698-5722.

Lyons T. W., Reinhard C. T. and Planavsky N. J. (2014) The rise of oxygen in Earth's early ocean and atmosphere. Nature 506, 307-315.

Martin M. W., Grazhdankin D. V., Bowring S. A., Evans D. A. D., Fedonkin M. A. and Kirschvink J. L. (2000) Age of Neoproterozoic bilaterian body and trace fossils, White Sea, Russia: Implications for metazoan evolution. Science 288, 841-845.

McFadden K. A., Huang J., Chu X., Jiang G., Kaufman A. J., Zhou C., Yuan X. and Xiao S. (2008) Pulsed oxidation and biological evolution in the Ediacaran Doushantuo Formation. Proc. Natl. Acad. Sci. USA 105, 3197-3202. 
927 928

McLennan S. M. (2001) Relationships between the trace element composition of sedimentary rocks and upper continental crust. Geochem. Geophys. Geosyst. 2 (2000GC000109).

Meffre S., Direen N. G., Crawford A. J. and Kamenetsky V. (2004) Mafic volcanic rocks on King Island, Tasmania: evidence for 579 Ma break-up in east Gondwana. Precambr. Res. 135, 177-191.

Miller C. A., Peucker-Ehrenbrink B., Walker B. D. and Marcantonio F. (2011) Re-assessing the surface cycling of molybdenum and rhenium. Geochim. Cosmochim. Acta 75, 7146-7179.

Mills D. B., Ward L. M., Jones C., Sweeten B., Forth M., Treusch A. H. and Canfield D. E. (2014) Oxygen requirements of the earliest animals. Proc. Natl. Acad. Sci. USA 111, $4168-4172$.

Montoya-Pino C., Weyer S., Anbar A. D., Pross J., Oschmann W., van de Schootbrugge B. and Arz H. W. (2010) Global enhancement of ocean anoxia during Oceanic Anoxic Event 2: a quantitative approach using $\mathrm{U}$ isotopes. Geology 38, 315-318.

Morford J. L. and Emerson S. (1999) The geochemistry of redox sensitive trace metals in sediments. Geochim. Cosmochim. Acta 63, 1735-1750.

Nägler T. F., Neubert N., Böttcher M. E., Dellwig O. and Schnetger B. (2011) Molybdenum isotope fractionation in pelagic euxinia: Evidence from the modern Black and Baltic Seas. Chem. Geol. 289, 1-11.

Nägler T. F., Anbar A. D., Archer C., Goldberg T., Gordon G. W., Greber N. D., Siebert C., Sohrin Y. and Vance D. (2014) Proposal for an international molybdenum isotope measurement standard and data representation. Geostand. Geoanal. Res. doi: 10.1111/j.1751-908X.2013.00275.x 
Nakagawa Y., Takano S., Firdaus M. L., Norisuye K., Hirata T., Vance D. and Sohrin Y. (2012) The molybdenum isotopic composition of the modern ocean. Geochem. J. 46, 131-141.

Narbonne G. M. and Gehling J. G. (2003) Life after snowball: The oldest complex Ediacaran fossils. Geology 31, 27-30.

Narbonne G. M., Laflamme M., Greentree C. and Trusler P. (2009) Reconstructing a lost world: Ediacaran rangeomorphs from Spaniard's Bay, Newfoundland. J. Paleontol. 83, 503-523.

Neubert N., Nägler T. F. and Böttcher M. E. (2008) Sulfidity controls molybdenum isotope fractionation into euxinic sediments: Evidence from the modern Black Sea. Geology 36, 775-778.

Noordmann J., Weyer S., Sharma M., Georg R., Rausch S. and Bach W. (2010) Fractionation of ${ }^{238} \mathrm{U} /{ }^{235} \mathrm{U}$ in rivers and hydrothermal systems: constraints for the oceanic $\mathrm{U}$ isotope cycle. AGU Fall Meeting, Abstract V31B-2330.

Noordmann J., Weyer S., Sharma M., Georg R. B., Rausch S. and Bach W. (2011) Fractionation of ${ }^{238} \mathrm{U} /{ }^{235} \mathrm{U}$ during weathering and hydrothermal alteration. Mineral. Mag. 75, 1548.

Och L. M. and Shields-Zhou G. A. (2012) The Neoproterozoic oxygenation event: Environmental perturbations and biogeochemical cycling. Earth-Sci. Rev. 110, 26-57.

Partin C. A., Bekker A., Planavsky N. J., Scott C. T., Bill B. C., Li C., Podkovyrov V., Maslov A., Konhauser K. O., Lalonde S. V., Love G. D., Poulton S. W. and Lyons T. W. (2013) Large-scale fluctuations in Precambrian atmospheric and oceanic oxygen levels from the record of U in shales. Earth Planet. Sci. Lett. 369-370, 284-293.

Pearce C. R., Cohen A. S., Coe A. L. and Burton K. W. (2008) Molybdenum isotope evidence for global ocean anoxia coupled with perturbations to the carbon cycle during the Early Jurassic. Geology 36, 231-234. 
972 Pearce C. R., Coe A. L. and Cohen A. S. (2010) Seawater redox variations during the deposition 973 of the Kimmeridge Clay Formation, United Kingdom (Upper Jurassic): Evidence from molybdenum isotopes and trace metal ratios. Paleoceanogr. 25, PA4213.

975 Pecoits E., Konhauser K. O., Aubet N. R., Heaman L. M., Veroslavsky G., Stern R. A. and 976 977 978 979 980 981 982 983 984 985 986 987 Gingras M. K. (2012) Bilaterian burrows and grazing behavior at >585 million years ago. Science 336, 1693-1696.

Penny A. M., Wood R., Curtis A., Bowyer F., Tostevin R. and Hoffman K.-H. (2014) Ediacaran metazoan reefs from the Nama Group, Namibia. Science 344, 1504-1506.

Planavsky N. J., Rouxel O. J., Bekker A., Lalonde S. V., Konhauser K. O., Reinhard C. T. and Lyons T. W. (2010) The evolution of the marine phosphate reservoir. Nature 467, 10881090.

Planavsky N. J., McGoldrick P., Scott C. T., Li C., Reinhard C. T., Kelly A. E., Chu X., Bekker A., Love G. D. and Lyons T. W. (2011) Widespread iron-rich conditions in the midProterozoic ocean. Nature 477, 448-451.

Planavsky N. J., Reinhard C. T., Wang X., Thomson D., McGoldrick P., Rainbird R. H., Johnson T., Fischer W. W. and Lyons T. W. (2014) Low Mid-Proterozoic atmospheric oxygen levels and the delayed rise of animals. Science 346, 635-638.

Poulson R. L., Siebert C., McManus J. and Berelson W. M. (2006) Authigenic molybdenum isotope signatures in marine sediments. Geology 34, 617-620.

991 Poulson Brucker R. L., McManus J., Severmann S. and Berelson W. M. (2009) Molybdenum 992 behavior during early diagenesis: Insights from Mo isotopes. Geochem. Geophys. 993 Geosyst. 10, Paper 2008GC002180. 
994 Poulton S. W. and Canfield D. E. (2005) Development of a sequential extraction procedure for 995 iron: implications for iron partitioning in continentally derived particulates. Chem. Geol. 214, 209-221.

997 Poulton S. W. and Canfield D. E. (2011) Ferruginous conditions: A dominant feature of the 998 ocean through Earth's history. Elements 7, 107-112.

999 Poulton S. W. and Raiswell R. (2002) The low-temperature geochemical cycle of iron: From 1000 continental fluxes to marine sediment deposition. Am. J. Sci. 302, 774-805.

1001 Poulton S. W., Fralick P. W. and Canfield D. E. (2004) The transition to a sulphidic ocean $\sim 1.84$ 1002 billion years ago. Nature 431, 173-177.

1003 1004 1005 1006 1007 1008 1009 1010 1011 1012 1013 1014 1015 1016

Proemse B. C., Grasby S. E., Wieser M. E., Mayer B. and Beauchamp B. (2013) Molybdenum isotopic evidence for oxic marine conditions during the latest Permian extinction. Geology 41, 967-970.

Raiswell R. and Canfield D. E. (1998) Sources of iron for pyrite formation in marine sediments. Am. J. Sci. 298, 219-245.

Reinhard C. T., Planavsky N. J., Robbins L. J., Partin C. A., Gill B. C., Lalonde S. V., Bekker A., Konhauser K. O. and Lyons T. W. (2013) Proterozoic ocean redox and biogeochemical stasis. Proc. Natl. Acad. Sci. USA 110, 5357-5362.

Retallack G. J., Marconato A., Osterhout J. T., Watts K. E. and Bindeman I. T. (2014) Revised Wonoka isotopic anomaly in South Australia and Late Ediacaran mass extinction. $J$. Geol. Soc. Lond. 171, 709-722.

Romaniello S. J., Herrmann A. D. and Anbar A. D. (2013) Uranium concentrations and ${ }^{238} U /{ }^{235} U$ isotope ratios in modern carbonates from the Bahamas: Assessing a novel paleoredox proxy. Chem. Geol. 362, 305-316. 
1017 Rogov V., Marusin V., Bykova N., Goy Y., Nagovitsin K., Kochnev B., Karlova G. and 1018 Grazhdankin D. (2012) The oldest evidence of bioturbation on Earth. Geology 40, 395-

1020

1021

1022

1023

1024

1025

1026

1027

1028

1029

1030

1031

1032

1033

1034

1035

1036

1037

1038

1039 398.

Runnegar B. (1991) Precambrian oxygen levels estimated from the biochemistry and physiology of early eukaryotes. Palaeogeogr. Palaeoclimatol. Palaeoecol. 97, 97-111.

Sahoo S. K., Planavsky N. J., Kendall B., Wang X., Shi X., Scott C., Anbar A. D., Lyons T. W. and Jiang G. (2012) Ocean oxygenation in the wake of the Marinoan glaciation. Nature 489, 546-549.

Sawaki Y., Ohno T., Tahata M., Komiya T., Hirata T., Maruyama S., Windley B. F., Han J., Shu D. and Li Y. (2010) The Ediacaran radiogenic Sr isotope excursion in the Doushantuo Formation in the Three Gorges area, South China. Precambr. Res. 176, 46-64.

Schauble E. A. (2006) Equilibrium uranium isotope fractionation by nuclear volume and massdependent processes. Eos Trans. AGU 87, Fall Meeting Suppl., Abstract V21B-0570.

Schiffbauer J. D., Xiao S., Sharma K. S. and Wang G. (2012) The origin of intracellular structures in Ediacaran metazoan embryos. Geology 40, 223-226.

Scholz F., McManus J. and Sommer S. (2013) The manganese and iron shuttle in a modern euxinic basin and implications for molybdenum cycling at euxinic ocean margins. Chem. Geol. 355, 56-68.

Scott C. and Lyons T. W. (2012) Contrasting molybdenum cycling and isotopic properties in euxinic versus non-euxinic sediments and sedimentary rocks: Refining the paleoproxies. Chem. Geol. 324-325, 19-27.

Scott C., Lyons T. W., Bekker A., Shen Y., Poulton S. W., Chu X. and Anbar A. D. (2008) Tracing the stepwise oxygenation of the Proterozoic ocean. Nature 452, 456-459. 
1040 Siebert C., Nägler T. F., von Blanckenburg F. and Kramers J. D. (2003) Molybdenum isotope 1041 records as a potential new proxy for paleoceanography. Earth Planet. Sci. Lett. 211, 159171.

1043 Siebert C., McManus J., Bice A., Poulson R. and Berelson W. M. (2006) Molybdenum isotope 1044 signatures in continental margin marine sediments. Earth Planet. Sci. Lett. 241, 723-733.

1045 Sperling E. A., Frieder C. A., Raman A. V., Girguis P. R., Levin L. A. and Knoll A. H. (2013a) 1046 Oxygen, ecology, and the Cambrian radiation of animals. Proc. Natl. Acad. Sci. USA 110, 1047 13446-13451.

1048

Sperling E. A., Halverson G. P., Knoll A. H., Macdonald F. A. and Johnston D. T. (2013b) A 1049 basin redox transect at the dawn of animal life. Earth Planet. Sci. Lett. 371-372, 143-155.

Stirling C. H., Andersen M. B., Potter E. K. and Halliday A. H. (2007) Low-temperature isotopic 1051 fractionation of uranium. Earth Planet. Sci. Lett. 264, 208-225.

1052 Tahata M., Ueno Y., Ishikawa T., Sawaki Y., Murakami K., Han J., Shu D., Li Y., Guo J., 1053 Yoshida N. and Komiya T. (2013) Carbon and oxygen isotope chemostratigraphies of the 1054 1055 Yangtze platform, South China: Decoding temperature and environmental changes through the Ediacaran. Gondwana Res. 23, 333-353.

Towe K. M. (1970) Oxygen-collagen priority and the early metazoan fossil record. Proc. Natl. 1057 Acad. Sci. USA 65, 781-788.

1058 Tribovillard N., Riboulleau A., Lyons T. and Baudin F. (2004) Enhanced trapping of 1059 molybdenum by sulfurized marine organic matter of marine origin in Mesozoic 1060 limestones and shales. Chem. Geol. 213, 385-401.

1061 Tribovillard N., Algeo T. J., Lyons T. and Riboulleau A. (2006) Trace metals as paleoredox and 1062 paleoproductivity proxies: An update. Chem. Geol. 232, 12-32. 
Verbruggen A. et al. (2008) Preparation and Certification of IRMM-3636, IRMM-3636a, and IRMM-3636b. Institute for Reference Materials and Measurements, $27 \mathrm{pp}$.

Wang J. and Li Z.-X. (2003) History of Neoproterozoic rift basins in South China: implications for Rodinia breakup. Precambr. Res. 261, 303-320.

Warren L. V., Pacheco M. L. A. F., Fairchild T. R., Simões M. G., Riccomini C., Boggiani P. C. and Cáceres A. A. (2012) The dawn of animal skeletogenesis: Ultrastructural analysis of the Ediacaran metazoan Corumbella werneri. Geology 40, 691-694.

Wasylenki L. E., Rolfe B. A., Weeks C. L., Spiro T. G. and Anbar A. D. (2008) Experimental investigation of the effects of temperature and ionic strength on Mo isotope fractionation during adsorption to manganese oxides. Geochim. Cosmochim. Acta 72, 5997-6005.

Weber B., Steiner M. and Zhu M. Y. (2007) Precambrian-Cambrian trace fossils from the Yangtze Platform (South China) and the early evolution of bilaterian lifestyles. Palaeogeogr. Palaeoclimatol. Palaeoecol. 254, 328-349.

Wen H., Carignan J., Zhang Y., Fan H., Cloquet C. and Liu S. (2011) Molybdenum isotopic records across the Precambrian-Cambrian boundary. Geology 39, 775-778.

Westermann S., Vance D., Cameron V., Archer C. and Robinson S. A. (2014) Heterogeneous oxygenation states in the Atlantic and Tethys oceans during Oceanic Anoxic Event 2. Earth Planet. Sci. Lett. 404, 178-189.

Weyer S., Anbar A. D., Gerdes A., Gordon G. W., Algeo T. J. and Boyle E. A. (2008) Natural fractionation of ${ }^{238} \mathrm{U} /{ }^{235} \mathrm{U}$. Geochim. Cosmochim. Acta 72, 345-359.

Wilby P. R., Carney J. N. and Howe M. P. A. (2011) A rich Ediacaran assemblage from eastern Avalonia: Evidence of early widespread diversity in the deep ocean. Geology 39, 655658. 
1086 Wille M., Nägler T. F., Lehmann B., Schröder S. and Kramers J. D. (2008) Hydrogen sulphide 1087 release to surface waters at the Precambrian/Cambrian boundary. Nature 453, 767-769.

Xiao S. and Laflamme M. (2009) On the eve of animal radiation: Phylogeny, ecology and 1089 evolution of the Ediacaran biota. Trends Ecol. Evol. 24, 31-40.

Xiao S., Yuan X., Steiner M. and Knoll A. H. (2002) Macroscopic carbonaceous compressions in a terminal Proterozoic shale: A systematic reassessment of the Miaohe Biota, South China. J. Paleontol. 76, 347-376.

Xiao S., Shen B., Zhou C., Xie G. and Yuan X. (2005) A uniquely preserved Ediacaran fossil 1094 with direct evidence for a quilted bodyplan. Proc. Natl. Acad. Sci. USA 102, 1022710232.

Xiao S., Zhou C. and Yuan X. (2007) Undressing and redressing Ediacaran embryos. Nature 446, E9-E11.

Xiao S., Knoll A. H., Schiffbauer J. D., Zhou C. and Yuan X. (2012) Comment on "Fossilized 1099 nuclei and germination structures identify Ediacaran animal embryos as encysting protists”. Science 335, 1169.

Xiao S., Zhou C., Liu P., Wang D. and Yuan X. (2014) Phosphatized acanthomorphic acritarchs and related microfossils from the Ediacaran Doushantuo Formation at Weng'an (South China) and their implications for biostratigraphic correlation. J. Paleontol. 88, 1-67. preserved inside diapause egg cysts. Nature 446, 661-663.

Yuan X., Chen Z., Xiao S., Zhou C. and Hua H. (2011) An early Ediacaran assemblage of macroscopic and morphologically differentiated eukaryotes. Nature 470, 390-393. 
Zhou C. and Xiao S. (2007) Ediacaran $\delta^{13} \mathrm{C}$ chemostratigraphy of South China. Chemical Geology 237, 89-108.

Zhou C., Xie G., McFadden K., Xiao S. and Yuan X. (2007) The diversification and extinction of Doushantuo-Pertatataka acritarchs in South China: causes and biostratigraphic significance. Geol. J. 42, 229-262.

Zhou L., Wignall P. B., Su J., Feng Q., Xie S., Zhao L. and Huang J. (2012) U/Mo ratios and $\delta^{98 / 95} \mathrm{Mo}$ as local and global redox proxies during mass extinction events. Chem. Geol. 324-325, 99-107.

Zhu B., Becker H., Jiang S. -Y., Pi D. -H., Fischer-Gödde M. and Yang, J. -H. (2013) Re-Os geochronology of black shales from the Neoproterozoic Doushantuo Formation, Yangtze platform, South China. Precambr. Res. 225, 67-76.

Zhu M., Zhang J. and Yang A. (2007) Integrated Ediacaran (Sinian) chronostratigraphy of South China. Palaeogeogr. Palaeoclimatol. Palaeoecol. 254, 7-61.

\section{FIGURE CAPTIONS}

Fig. 1. (a) Paleogeographic map of the Yangtze platform at $\sim 600$ Ma showing the location of the Three Gorges region. (b) Geological map of the Yangtze Gorges area, showing the location of the Jiulongwan outcrop section. The enclosed region is expanded in (c) to show the location of the drill core section (Site 1), which is $\sim 5 \mathrm{~km}$ away from the Jiulongwan section in the Three Gorges region. (d) Cross-section along line A-B in (c) showing the Neoproterozoic stratigraphy and location of the Site \#1 core. Modified from Sawaki et al. (2010) and Tahata et al. (2013). 
1131 Fig. 2. Geochemical profiles through Member IV, Doushantuo Formation. Stratigraphic columns

1132 of the Jiulongwan outcrop section and the Site 1 drill core section are modified from McFadden

1133 et al. (2008) and Sawaki et al. (2010), respectively (NF = glaciogenic Nantuo Formation; DF =

1134 Dengying Formation). The ovals within the black shale in the Jiulongwan section represent

1135 dolomite nodules. The error bars in the isotope profiles denote the long-term reproducibility of

1136 our secondary standards ( $\sim 0.15 \%$ for Mo and $\sim 0.07 \%$ for U; 2SD). For clarity, individual

1137 sample error bars are not shown. Total organic carbon, total Fe, highly reactive Fe and pyrite Fe

1138 are denoted by $\mathrm{TOC}, \mathrm{Fe}_{\mathrm{T}}, \mathrm{Fe}_{\mathrm{HR}}$, and $\mathrm{Fe}_{\mathrm{PY}}$, respectively. Sediments deposited from anoxic bottom

1139 waters typically have $\mathrm{Fe}_{\mathrm{HR}} / \mathrm{Fe}_{\mathrm{T}}>0.38$, and $\mathrm{Fe}_{\mathrm{PY}} / \mathrm{Fe}_{\mathrm{HR}}$ distinguishes between euxinic $(>0.7)$ and

1140 ferruginous $(<0.7)$ conditions.

1141

1142 Fig. 3. (a) Mo EF versus U EF for the Member IV ORM. The dashed lines are equivalent to the

1143 molar Mo/U ratio for modern seawater $(1 \times \mathrm{SW})$ and for a fraction of modern seawater $(0.3 \times$

1144 SW), following Algeo and Tribovillard (2009). Green squares = Jiulongwan outcrop section. Red

1145 triangles $=$ Site 1 drill core section. Large filled symbols $=$ samples with highest $\delta^{98}$ Mo from

1146 each section. (b) $\delta^{98}$ Mo versus $\delta^{238} U$ for the Member IV ORM, showing no correlation between

1147 the two isotope systems $\left(\mathrm{R}^{2}<0.3\right.$ for both sections). Symbols are the same as in (a).

1149 Fig. 4. Temporal record of $\delta^{98} \mathrm{Mo}$ and associated Mo/TOC data from euxinic ORM, since the end 1150 of the Great Oxidation Event. Large squares represent the highest $\delta^{98}$ Mo for that time, with other 1151 data represented by small circles (red: 2050-640 Ma; orange: 555-530 Ma; blue: 520-440 Ma;

1152 green: 390-0 Ma). (a) Mo isotope record over the past $2050 \mathrm{Ma}$, with the 800-0 Ma interval 1153 expanded in (b) (Dsh IV = Doushantuo Formation, Member IV). (c) Cross plot of average 
$1154 \mathrm{Mo} / \mathrm{TOC}$ ratio versus highest $\delta^{98} \mathrm{Mo}$ (Mo/TOC data is not available for all intervals). Black Sea 1155 euxinic sediments have low Mo/TOC because of basin restriction (Algeo and Lyons, 2006). 1156 Three Mesozoic intervals also have low Mo/TOC because of a transient expansion of ocean 1157 anoxia (the highest $\delta^{98}$ Mo from the Jurassic sections mark a return to widespread ocean 1158 oxygenation; Pearce et al., 2008, 2010; Westermann et al., 2014). (d) Temporal comparison of 1159 known episodes of extensive ocean oxygenation (green bars), the Shuram-Wonoka carbon 1160 isotope anomaly, and the appearance of complex macroscopic metazoans (modified from Sawaki 1161 et al., 2010). The extent of ocean oxygenation at the start of the Shuram excursion is not known 1162 (see text for discussion). Data sources: $\delta^{98}$ Mo (Barling et al., 2001; Arnold et al., 2004; Lehmann 1163 et al., 2007; Wille et al., 2008; Neubert et al., 2008; Pearce et al., 2008; 2010; Gordon et al., 1164 2009; Kendall et al., 2009a, 2011; Dahl et al., 2010b, 2011; Dickson and Cohen, 2012; Dickson 1165 et al., 2012; Herrmann et al., 2012; Zhou et al., 2012; Asael et al., 2013; Proemse et al., 2013; 1166 Westermann et al., 2014; this study), Shuram-Wonoka anomaly (McFadden et al., 2008; Sawaki 1167 et al., 2010; Tahata et al., 2013), acanthomorph acritarchs (Yin et al., 2007; McFadden et al., 1168 2008), animal embryos (Yin et al., 2007), Ediacara fossils (Narbonne and Gehling, 2003), motile 1169 metazoans (Liu et al., 2010; Pecoits et al., 2012), macroscopic motile bilaterians (Martin et al., 1170 2000), and weakly calcified metazoans (Grotzinger et al., 1995). 


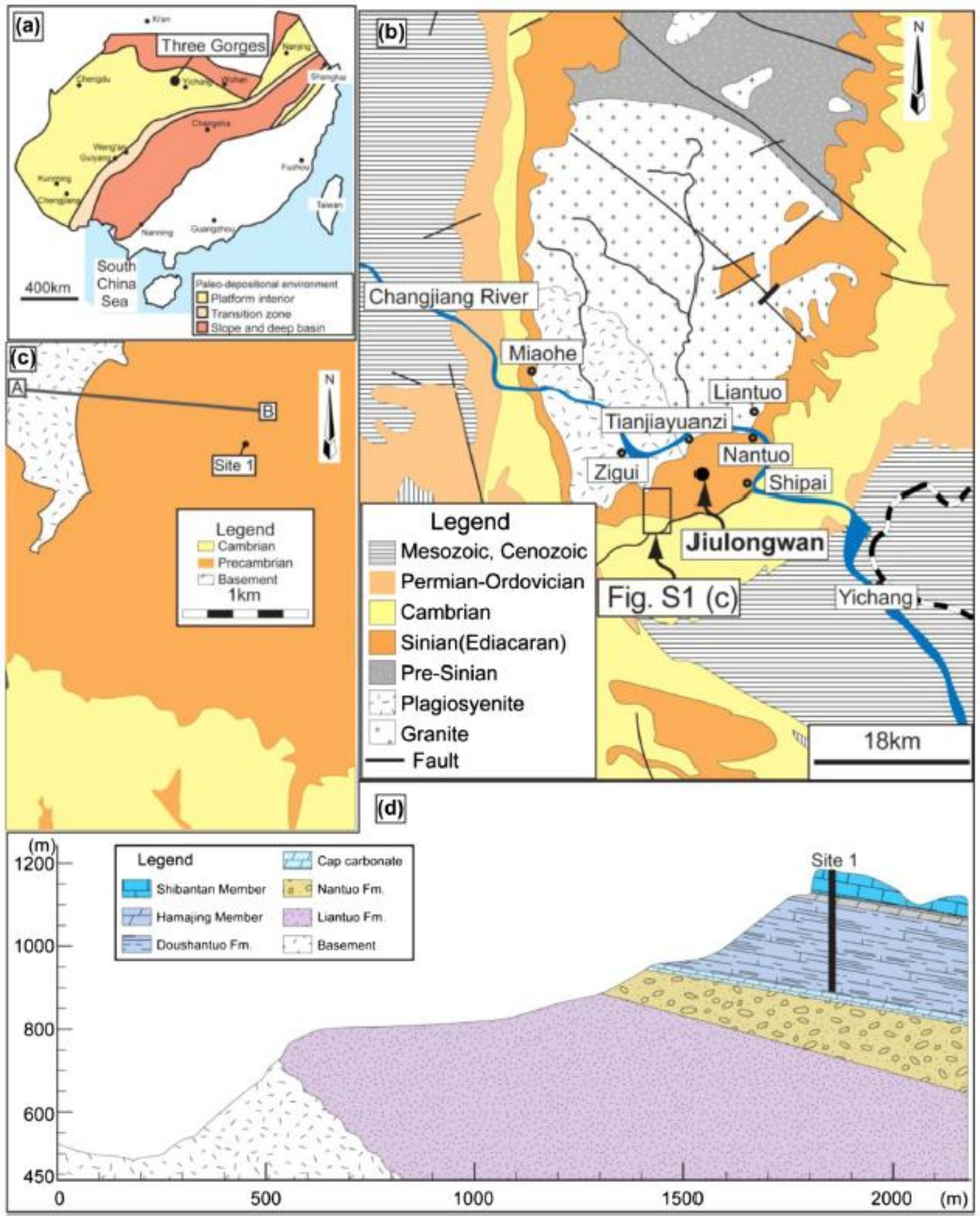



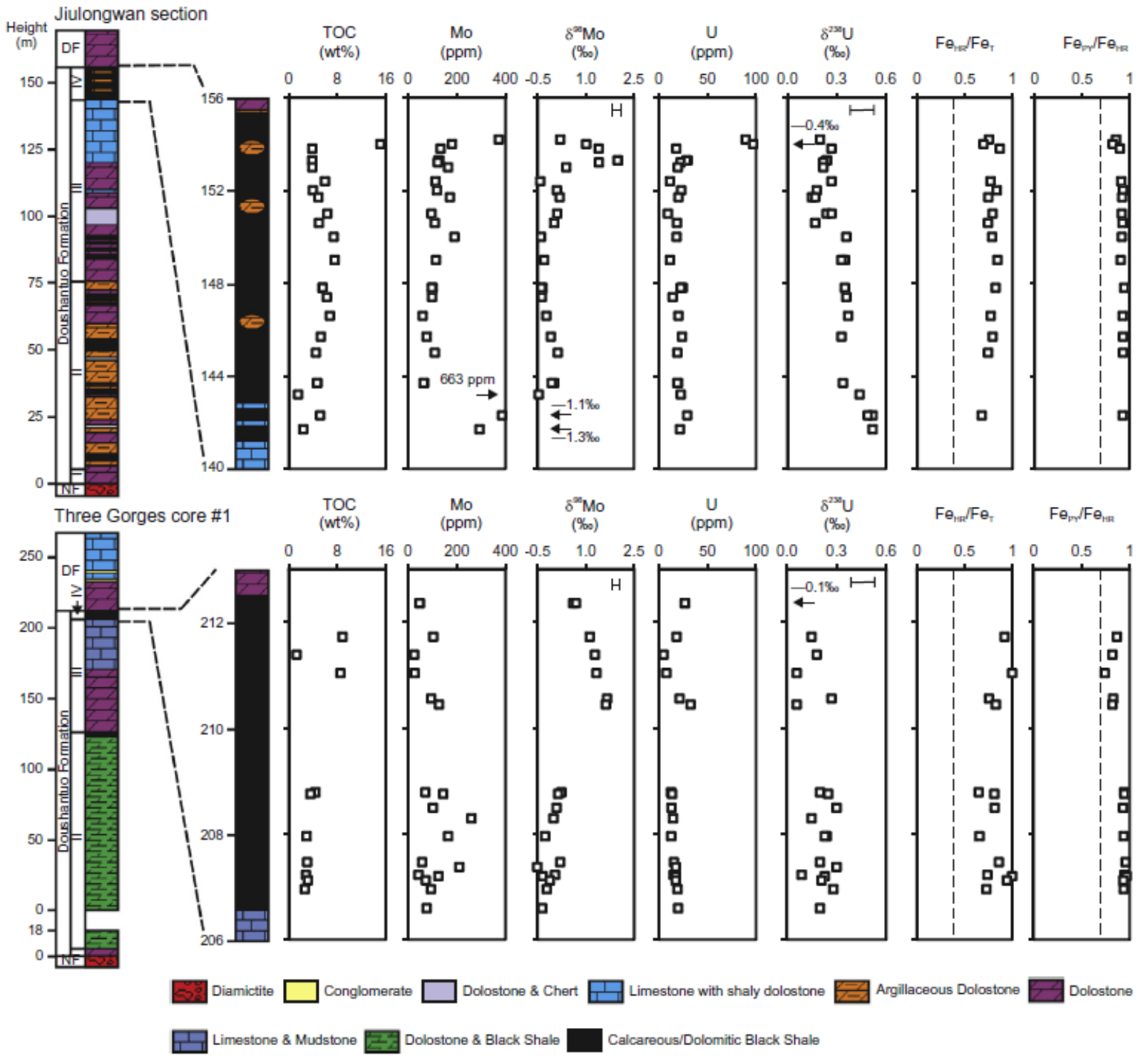


\section{$1188 \quad$ Figure 3}

1189
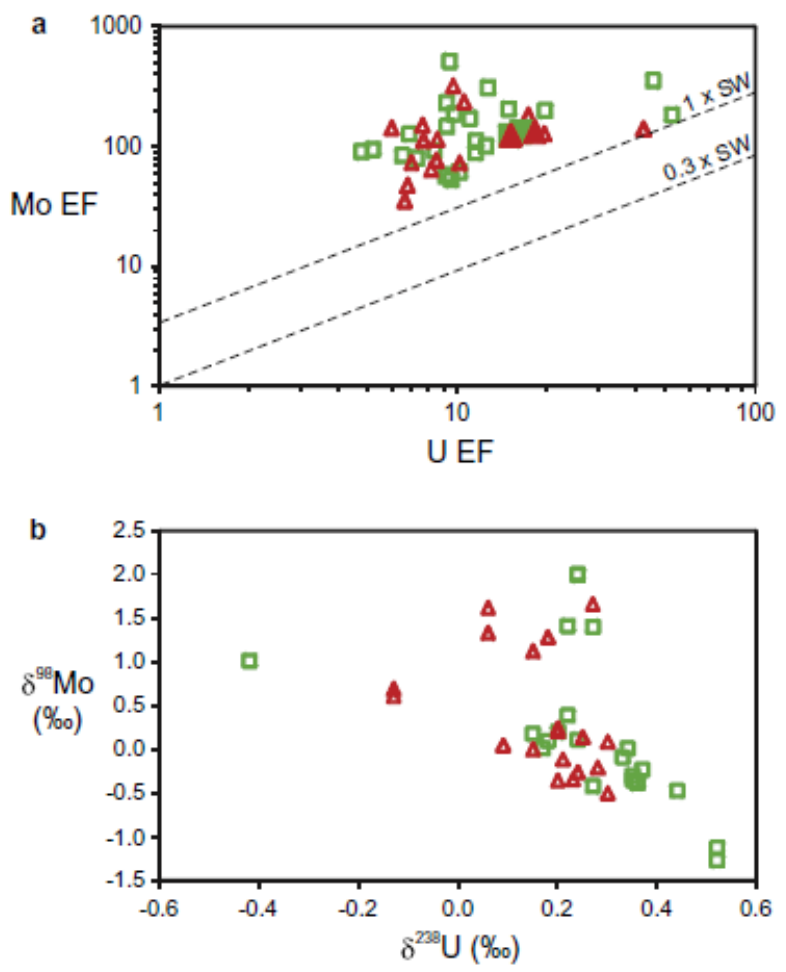

1190

1191

1192

1193

1194

1195

1196

1197

1198

1199

1200

1201 

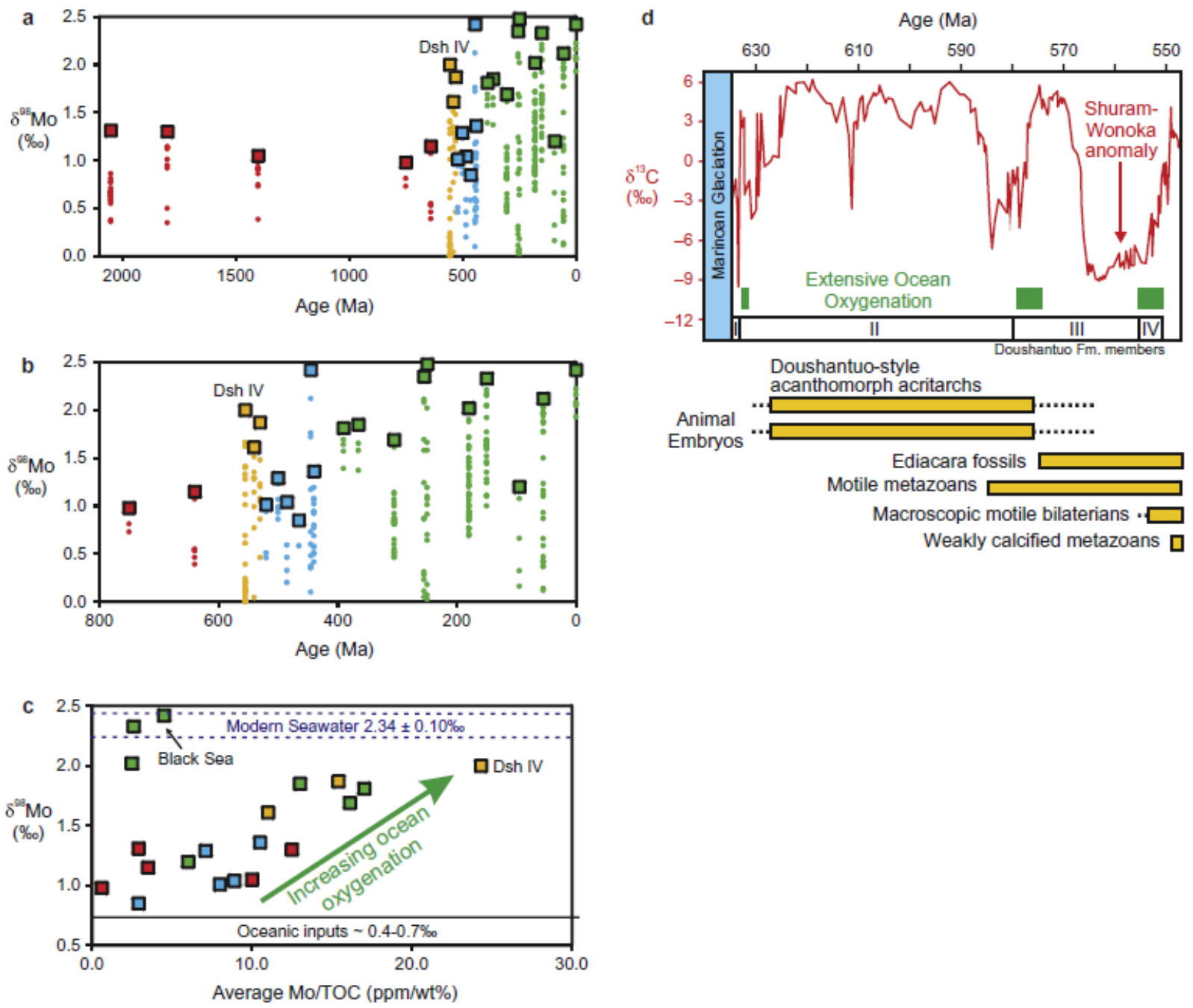
Table 1

Geochemical data for Member IV, Doushantuo Formation, Three Gorges region, South China.

\begin{tabular}{|c|c|c|c|c|c|c|c|c|c|c|c|c|c|c|c|c|c|c|c|c|c|c|c|c|c|}
\hline Sample & $\begin{array}{l}\begin{array}{l}\text { Height } \\
(\mathrm{m})\end{array} \\
\end{array}$ & $\begin{array}{l}\mathrm{TOC}^{b} \\
\text { (wt\%) }\end{array}$ & $\begin{array}{l}\mathrm{Al} \\
\text { (we\%) }\end{array}$ & $\begin{array}{l}\begin{array}{l}\text { Mo } \\
(\mathrm{ppm})\end{array} \\
\end{array}$ & $\begin{array}{l}\text { Mo } \\
\mathrm{EF}\end{array}$ & $\begin{array}{l}\begin{array}{l}\mathrm{Mo} / \mathrm{TOC} \\
(\mathrm{ppm} / \mathrm{wt} \%)\end{array} \\
\end{array}$ & $\begin{array}{l}\delta^{2 \mathrm{Mo}^{*}} \\
(\%)\end{array}$ & $\begin{array}{l}\delta^{52} \mathrm{M}^{4} \\
(\%)\end{array}$ & $\begin{array}{l}\text { 2SD } \\
\text { Measured }\end{array}$ & $\begin{array}{l}\text { 2SD } \\
\text { Reportod }\end{array}$ & $n^{r}$ & $\begin{array}{l}\mathrm{U} \\
(\mathrm{ppm})\end{array}$ & $\begin{array}{l}\mathrm{U} \\
\mathrm{EF}\end{array}$ & $\begin{array}{l}8^{228} \mathrm{U} \\
(\%)\end{array}$ & $\begin{array}{l}\text { 2SD } \\
\text { Measured }\end{array}$ & $\begin{array}{l}2 \mathrm{SDD}^{8} \\
\text { Reported }\end{array}$ & $n^{r}$ & 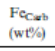 & $\begin{array}{l}\mathrm{Fe}_{\mathrm{O}} \\
(\mathrm{wt} \%)\end{array}$ & $\begin{array}{l}\mathrm{Fc}_{\mathrm{M}} \\
\text { (wt\%) }\end{array}$ & $\begin{array}{l}\mathrm{Fe}_{\mathrm{py}} \\
(\mathrm{w} \%)\end{array}$ & $\begin{array}{l}\mathrm{Fe}_{\mathrm{RR}}^{\mathrm{h}} \\
(\mathrm{wt} \%)\end{array}$ & $\begin{array}{l}\begin{array}{l}\mathrm{For}^{1} \\
(\mathrm{wt} \%)\end{array} \\
\end{array}$ & $\begin{array}{l}\mathrm{Fe}_{\mathrm{HR}} / \\
\mathrm{Fe}_{\mathrm{T}} \\
\end{array}$ & $\begin{array}{l}\mathrm{Fe}_{\mathrm{PV} /} \\
\mathrm{Fe}_{\mathrm{HR}}\end{array}$ \\
\hline \multicolumn{26}{|c|}{ Llongwan Outcrop Section } \\
\hline HND 41.4 & 154.2 & & 5.6 & 372 & 353 & & 0.28 & 0.20 & 0.01 & 0.15 & 3 & 89 & 45 & 0.20 & 0.10 & 0.10 & 3 & 0.2 & 0.2 & 0.0 & 2.4 & 2.8 & 3.7 & 0.75 & 0.86 \\
\hline $\begin{array}{l}\mathrm{HN}-23^{* \prime} \\
\mathrm{HN}-23 \mathrm{rpt}\end{array}$ & $\begin{array}{l}154.0 \\
154.0\end{array}$ & 15.1 & 5.3 & 181 & 183 & 12 & 1.09 & 1,01 & 0.08 & 0.15 & ${ }^{3}$ & 97 & 52 & $\begin{array}{l}-0.42 \\
-0.37\end{array}$ & $\begin{array}{l}0.09 \\
0.07\end{array}$ & $\begin{array}{l}0.09 \\
0.07\end{array}$ & 3 & 0.2 & 0.1 & 0.0 & 1.9 & 2.3 & 3.3 & 0.70 & 0.83 \\
\hline $\begin{array}{l}\text { HN-23rpt } \\
\text { HND } 41.0^{\circ}\end{array}$ & $\begin{array}{l}154.0 \\
153.8\end{array}$ & 3.9 & 3.5 & 134 & 204 & 34 & 1.48 & 1.40 & 0.10 & 0.15 & 5 & 18 & 15 & $\begin{array}{r}-0.37 \\
0.27\end{array}$ & $\begin{array}{l}0.07 \\
0.02\end{array}$ & $\begin{array}{l}0.07 \\
0.07\end{array}$ & $\begin{array}{l}3 \\
3\end{array}$ & 0.1 & 0.1 & 0.0 & 1.7 & 19 & 2.1 & 0.87 & 0.90 \\
\hline $\begin{array}{l}\text { HND } \\
40.5\end{array}$ & 153.3 & 3.9 & 5.2 & 128 & 132 & 33 & 2.08 & 2.00 & 0.20 & 0.20 & 3 & 30 & 16 & 0.24 & 0.03 & 0.07 & 3 & & & & & & 3.1 & & \\
\hline $\begin{array}{l}\text { HND } \ldots . \\
40.5 \text { rpt }\end{array}$ & 153.3 & 3.9 & 5.5 & 125 & 123 & 32 & 2.07 & 1.99 & 0.06 & 0.15 & 3 & 29 & 15 & 0.24 & 0.06 & 0.07 & 3 & & & & & & 3.5 & & \\
\hline HND 40.4 . & 153.2 & & 3.3 & 123 & 199 & & 1.49 & 1.41 & 0.13 & 0.15 & 3 & 23 & 20 & 0.22 & 0.07 & 0.07 & 4 & & & & & & 2.2 & & \\
\hline HND $40.2^{\circ}$. & 153.0 & 3.9 & 5.2 & 165 & 171 & 42 & 0.47 & 0.39 & 0.07 & 0.15 & 5 & 20 & 11 & 0.22 & 0.04 & 0.07 & 3 & & & & & & 2.6 & & \\
\hline HND $39.6^{\circ}$ & 152.4 & 6.0 & 6.4 & 113 & 94 & 19 & -0.34 & -0.42 & 0.13 & 0.15 & 7 & 12 & 5.2 & 0.27 & 0.03 & 0.07 & 4 & 0.1 & 0.1 & 0.0 & 2.0 & 2.2 & 2.8 & 0.77 & 0.91 \\
\hline $\begin{array}{l}\text { HND } \\
39.2 .\end{array}$ & 152.0 & 4.0 & 5.8 & 119 & 110 & 30 & 0.18 & 0.10 & 0.18 & 0.18 & 8 & 23 & 12 & 0.18 & 0.05 & 0.07 & 3 & 0.1 & 0.1 & 0.0 & 2.1 & 2.2 & 2.6 & 0.84 & 0.93 \\
\hline $\begin{array}{l}\text { HND } 38.9^{\circ} \\
\text { HND }\end{array}$ & $\begin{array}{l}151.7 \\
151.7\end{array}$ & 4.9 & 6.3 & 172 & 146 & 35 & 0.26 & 0.18 & 0.15 & 0.15 & 6 & 20 & 9.2 & $\begin{array}{l}0.15 \\
0.17\end{array}$ & $\begin{array}{l}0.08 \\
0.01\end{array}$ & $\begin{array}{l}0.08 \\
0.07\end{array}$ & $\begin{array}{l}7 \\
4\end{array}$ & 0.1 & 0.1 & 0.0 & 2.0 & 2.1 & 2.8 & 0.75 & 0.92 \\
\hline $\begin{array}{l}\text { 38.9rpt" } \\
\text { HND }\end{array}$ & & 64 & 57 & & ${ }_{90}$ & 15 & & & & 015 & & & & 024 & & & & & 01 & 0.0 & 21 & 23 & 29 & 079 & 0.92 \\
\hline 38. & 151.0 & 6.4 & 3.1 & $\$ 0$ & (50 & 15 & 0.19 & 0.11 & 0.14 & 0.15 & r & 10 & 4.8 & 0.24 & 0.04 & 0.07 & 3 & 0.1 & 0.1 & 0.0 & 2.1 & 2,3 & 2.9 & 0.79 & 0.92 \\
\hline $\begin{array}{l}\text { HND } \\
\text { 38.2rpt... }\end{array}$ & 151,0 & & & & & & & & & & & & & 0.27 & 0.06 & 0.07 & 3 & & & & & & & & \\
\hline HND $37.8^{\circ}$ & 150.6 & 5.0 & 6.4 & 110 & 92 & 22 & 0.09 & 0.01 & 0.16 & 0.16 & 7 & 19 & 8.3 & 0.17 & 0.08 & 0.08 & 3 & 0.1 & 0.1 & 0.0 & 1.9 & 2.0 & 2.7 & 0.74 & 0.93 \\
\hline $\begin{array}{l}\text { HND } \\
36.85\end{array}$ & 150.0 & 7.5 & 5.5 & 191 & 186 & 26 & -0.31 & -0.39 & 0.13 & 0.15 & 7 & 19 & 10 & 0.36 & 0.09 & 0.09 & 3 & 0.1 & 0.1 & 0.0 & 1.8 & 19 & 2.4 & 0.79 & 0.92 \\
\hline $\begin{array}{l}\text { HND } 36.2^{\circ} \\
\text { HND } \\
36.2 \mathrm{rpt}^{\circ}\end{array}$ & $\begin{array}{l}149.0 \\
149.0\end{array}$ & 7.6 & 4.9 & 115 & 126 & 15 & -0.22 & -0.30 & 0.15 & 0.15 & 7 & 12 & 6.9 & $\begin{array}{l}0.35 \\
0.33\end{array}$ & $\begin{array}{l}0.01 \\
0.05\end{array}$ & $\begin{array}{l}0.07 \\
0.07\end{array}$ & $\begin{array}{l}3 \\
3\end{array}$ & 0.1 & 0.1 & 0.0 & 1.6 & 1.8 & 2.1 & 0.84 & 0.91 \\
\hline $\begin{array}{l}\text { 3.0.2Pt } \\
\text { HND... } \\
35.0\end{array}$ & 147.8 & 5.6 & 6.2 & 102 & 88 & 18 & -0.27 & -0.35 & 0.13 & 0.15 & 8 & 25 & 11 & 0.35 & 0.04 & 0.07 & 4 & 0.1 & 0.1 & 0.0 & 2.3 & 2.4 & 2.9 & 0.82 & 0.95 \\
\hline $\begin{array}{l}\text { HND } \\
\text { 35.0rpt... }\end{array}$ & 147.8 & 5.6 & 5.2 & 98 & 100 & 17 & -0.30 & -0.38 & 0.07 & 0.15 & 3 & 23 & 12 & & & & & & & & & & 2.8 & & \\
\hline HND $34,6^{\circ}$. & 147.4 & 6.3 & 6.4 & 99 & 83 & 16 & -0.29 & -0.37 & 0.12 & 0.15 & 5 & 14 & 6.5 & 0.36 & 0.06 & 0.07 & 3 & & & & & & 2.8 & & \\
\hline HND $33.8^{\circ}$ & 146.6 & 6.8 & 6.1 & 60 & 53 & 8.8 & -0.15 & -0.23 & 0.12 & 0.15 & 5 & 20 & 10 & 0.37 & 0.09 & 0.09 & 3 & 0.1 & 0.1 & 0.0 & 1.8 & 19 & 2.5 & 0.77 & 0.93 \\
\hline $\begin{array}{l}\text { HND. } \\
32.9^{*}\end{array}$ & 145.7 & 5.3 & 6.8 & 77 & 61 & 14 & -0.01 & -0.09 & 0.19 & 0.19 & 8 & 24 & 10 & 0.33 & 0.08 & 0.08 & 3 & 0.1 & 0.1 & 0.0 & 2.1 & 2.2 & 2.8 & 0.79 & 0.93 \\
\hline HND $32.2^{\circ}$ & 145.0 & 4.5 & 7.5 & 110 & 79 & 24 & 0.21 & 0.13 & 0.17 & 0.17 & 7 & 19 & 7.3 & & & & & 0.1 & 0.1 & 0.0 & 2.3 & 2.5 & 3.3 & 0.75 & 0.93 \\
\hline $\begin{array}{l}\text { HND. } \\
30.9^{\cdots}\end{array}$ & 143.7 & 4.7 & 6.3 & 66 & 57 & 14 & 0.09 & 0.01 & 0.19 & 0.19 & 6 & 20 & 9.1 & 0.34 & 0.06 & 0.07 & 3 & & & & & & 3.1 & & \\
\hline $\begin{array}{l}\text { HND } \\
30.9 \text { rpt }\end{array}$ & 143.7 & 4.7 & 6.0 & 64 & 57 & 14 & 0.02 & -0.06 & 0.10 & 0.15 & 3 & 19 & 9.2 & & & & & & & & & & 3.0 & & \\
\hline $\begin{array}{l}\text { HND } \\
30.35\end{array}$ & 143.2 & 1.6 & 6.9 & 663 & 512 & 420 & -0.39 & -0.47 & 0.15 & 0.15 & 7 & 23 & 9.4 & 0.44 & 0.08 & 0.08 & 7 & & & & & & 2.5 & & \\
\hline $\begin{array}{l}\text { HND } 29.5^{\circ} \\
\text { HND }\end{array}$ & $\begin{array}{l}142,3 \\
142,3\end{array}$ & 5.2 & 6.7 & 385 & 309 & 74 & -1.04 & -1.12 & 0.13 & 0.15 & 7 & 29 & 13 & $\begin{array}{l}0.52 \\
0.49\end{array}$ & $\begin{array}{l}0.10 \\
0.11\end{array}$ & $\begin{array}{l}0.10 \\
0.11\end{array}$ & $\begin{array}{l}3 \\
6\end{array}$ & 0.1 & 0.1 & 0.0 & 1.8 & 2.0 & 2.9 & 0.68 & 0.93 \\
\hline $\begin{array}{l}29.5 \mathrm{spt} \\
\text { HND } 28.85^{\circ}\end{array}$ & 141.7 & 2.4 & 6.8 & 294 & 230 & 123 & -1.19 & -1.27 & 0.17 & 0.17 & 7 & 22 & 9.2 & 0.52 & 0.05 & 0.07 & 4 & & & & & & 2.4 & & \\
\hline
\end{tabular}

1214

\begin{tabular}{|c|c|c|c|c|c|c|c|c|c|c|c|c|c|c|c|c|c|c|c|c|c|c|c|c|c|}
\hline Sample $e^{2}$ & $\begin{array}{l}\text { Height } \\
(\mathrm{m})\end{array}$ & $\begin{array}{l}\operatorname{TOC}^{b} \\
\left(\mathrm{w}^{\mathrm{B}} /\right)^{2}\end{array}$ & $\begin{array}{l}\mathrm{Al} \\
(\mathrm{wt} \%)\end{array}$ & $\begin{array}{l}\text { Mo } \\
\text { (ppm) }\end{array}$ & $\begin{array}{l}\text { Mo } \\
\text { EF }\end{array}$ & $\begin{array}{l}\text { Mo/TOC } \\
(\mathrm{ppm} / \mathrm{wt} \%)\end{array}$ & $\begin{array}{ll}8^{9 \mathrm{M}^{\circ} \mathrm{M}}{ }^{\circ} \\
(\%)\end{array}$ & $\begin{array}{l}8^{28} \mathrm{Mo}^{4} \\
(\%)\end{array}$ & $\begin{array}{ll}\text { 2SD } \\
\text { Measured }\end{array}$ & $\begin{array}{l}\text { SDD }^{e} \\
\text { Reportad }\end{array}$ & $n^{r}$ & $\begin{array}{l}\mathrm{u} \\
(\mathrm{ppm})\end{array}$ & $\begin{array}{ll}\mathrm{U} \\
\mathrm{EF}\end{array}$ & $\begin{array}{l}8^{228} U \\
(\%)\end{array}$ & $\begin{array}{ll}\text { 2SD } \\
\text { Measured }\end{array}$ & $\begin{array}{l}2 \mathrm{SD}^{8} \\
\text { Reportad }\end{array}$ & $n^{t}$ & $\begin{array}{l}\text { Fecab } \\
(w 0 \%)\end{array}$ & $\begin{array}{l}\mathrm{Feok} \\
(\mathrm{w} t \%)\end{array}$ & $\begin{array}{l}\text { Femas } \\
(\mathrm{w} / \%)\end{array}$ & $\begin{array}{l}\mathrm{Fcpy} \\
(\mathrm{wt} \%)\end{array}$ & $\begin{array}{l}F_{\text {FerR }}^{\text {h }} \\
\text { (wt\%) }\end{array}$ & 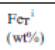 & $\begin{array}{l}\text { Feнr/ } \\
\text { Fer }_{\mathrm{T}}\end{array}$ & $\begin{array}{l}\mathrm{Fepr}_{\mathrm{P} /} \\
\mathrm{Fe}_{\mathrm{HR}}\end{array}$ \\
\hline \multicolumn{26}{|c|}{ Three Gorges Core \#I } \\
\hline 40,4 of 12 & 212.35 & & 1.8 & 48 & 140 & & 0.69 & 0.61 & 0.08 & 0.15 & 3 & 27 & 42 & -0.13 & 0.07 & 0.07 & 4 & & & & & & 1.1 & & \\
\hline \multicolumn{26}{|c|}{ 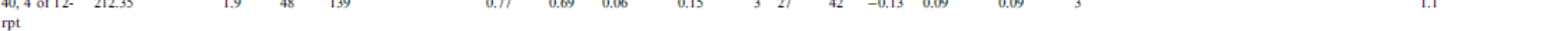 } \\
\hline s104012 & 211.72 & 8.9 & 3.1 & 104 & 181 & 12 & 1.20 & 1.12 & 0.07 & 0.15 & 4 & 19 & 17 & 0.15 & 0.05 & 0.07 & 3 & 0.1 & 0.1 & 0.0 & 1.3 & 1.5 & 1.7 & 0.92 & 0.87 \\
\hline S104103 & 211.38 & 1.3 & & 25 & & 19 & 1.36 & 1.28 & 0.21 & 0.21 & 7 & 5 & & 0.18 & 0.10 & 0.10 & 4 & 0.1 & 0.1 & 0.0 & 0.6 & 0.8 & & & 0.82 \\
\hline S104106 & 211.03 & 8.6 & 1.2 & 27 & 126 & 3.2 & 1.41 & 1.33 & 0.14 & 0.15 & 5 & 8 & 20 & 0.06 & 0.01 & 0.07 & 4 & 0.1 & 0.1 & 0.0 & 0.4 & 0.6 & 0.6 & 1.00 & 0.74 \\
\hline 41,11 of 14 & 210.55 & & 4.1 & 95 & 123 & & 1.74 & 1.66 & 0.20 & 0.20 & 3 & 22 & 15 & 0.27 & 0.07 & 0.07 & 4 & 0.3 & 0.1 & 0.0 & 1.8 & 2.1 & 2.8 & 0.76 & 0.83 \\
\hline 41,13 of 14 & 210.44 & & 5.2 & 127 & 132 & & 1.70 & 1.62 & 0.17 & 0.17 & 3 & 33 & 18 & 0.06 & 0.05 & 0.07 & 3 & 0.4 & 0.1 & 0.0 & 2.3 & 29 & 3.4 & 0.83 & 0.82 \\
\hline S104206-A1 & 208.78 & 4.4 & 5.2 & 71 & 73 & 16 & 0.32 & 0.24 & 0.21 & 0.21 & 5 & 13 & 7.0 & 0.20 & 0.03 & 0.07 & 3 & 0.0 & 0.1 & 0.0 & 1.8 & 19 & 2.9 & 0.65 & 0.94 \\
\hline S104206-A2 & 208.75 & 3.6 & 5.2 & 145 & 150 & 40 & 0.22 & 0.14 & 0.13 & 0.15 & 4 & 14 & 7.6 & 0.25 & 0.03 & 0.07 & 3 & 0.1 & 0.1 & 0.0 & 2.2 & 2.4 & 2.9 & 0.81 & 0.94 \\
\hline 42,6 of 7,1 & 208.49 & & 4.9 & 102 & 111 & & 0.17 & 0.09 & 0.09 & 0.15 & 3 & 13 & 7.7 & 0.30 & 0.10 & 0.10 & 5 & 0.1 & 0.1 & 0.0 & 1.8 & 2.0 & 2.4 & 0.82 & 0.93 \\
\hline 42,6 of 7,6 & 208.29 & & 4.4 & 261 & 320 & & 0.08 & 0.00 & 0.18 & 0.18 & 3 & 15 & 10 & 0.15 & 0.14 & 0.14 & 7 & & & & & & 2.3 & & \\
\hline S104301B & 207.95 & 3.0 & 6.2 & 164 & 142 & 55 & -0.18 & -0.26 & 0.16 & 0.16 & 5 & 13 & 6.0 & 0.24 & 0.07 & 0.07 & 4 & 0.0 & 0.1 & 0.0 & 1.8 & 19 & 2.9 & 0.66 & 0.94 \\
\hline $\begin{array}{l}\text { s104301Brpt } \\
\text { sis }\end{array}$ & 207.95 & 3.0 & 0.2 & Tor & 142 & m & -0.10 & -0.20 & .10 & 0.10 & 3 & 13 & 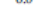 & 0.23 & 0.08 & 0.08 & 4 & 0.0 & 0.1 & 0,0 & 1,0 & 10 & 2.9 & 0.00 & 098 \\
\hline S104304 & 207.46 & 3.1 & 6.6 & 58 & 47 & 19 & 0.29 & 0.21 & 0.18 & 0.18 & 5 & 16 & 6.8 & 0.20 & 0.04 & 0.07 & 3 & 0.0 & 0.1 & 0.0 & 2.6 & 2.7 & 3.1 & 0.86 & 0.96 \\
\hline \multirow{2}{*}{\multicolumn{26}{|c|}{$-0.42-5.30 \quad 0.11$}} \\
\hline & & & & & & & & & & & & & & & & & & & & & & & & & \\
\hline $\begin{array}{l}\text { S104306 } \\
43,6 \text { of } 6\end{array}$ & $\begin{array}{l}207.22 \\
207.20\end{array}$ & 2.9 & $\begin{array}{l}6.7 \\
5.9\end{array}$ & $\begin{array}{r}44 \\
125\end{array}$ & $\begin{array}{r}35 \\
114\end{array}$ & 15 & $\begin{array}{r}0.13 \\
-0.26\end{array}$ & $\begin{array}{r}0.05 \\
-0.34\end{array}$ & $\begin{array}{l}0.09 \\
0.11\end{array}$ & $\begin{array}{l}0.15 \\
0.15\end{array}$ & $\begin{array}{l}4 \\
3\end{array}$ & $\begin{array}{l}15 \\
18\end{array}$ & $\begin{array}{l}6.7 \\
8.6\end{array}$ & $\begin{array}{l}0.09 \\
0.23\end{array}$ & $\begin{array}{l}0.04 \\
0.05\end{array}$ & $\begin{array}{l}0.07 \\
0.07\end{array}$ & $\begin{array}{l}4 \\
4\end{array}$ & $\begin{array}{l}0.0 \\
0.0\end{array}$ & $\begin{array}{l}0.1 \\
0.1\end{array}$ & $\begin{array}{l}0.0 \\
0.0\end{array}$ & $\begin{array}{l}2.1 \\
3.2\end{array}$ & $\begin{array}{l}2.2 \\
3.3\end{array}$ & $\begin{array}{l}3.0 \\
2.9\end{array}$ & $\begin{array}{l}0.74 \\
1.00\end{array}$ & $\begin{array}{l}0.94 \\
0.97\end{array}$ \\
\hline S104401 & 207.12 & 3.2 & 6.1 & 73 & 64 & 23 & -0.03 & -0.11 & 0.17 & 0.17 & 5 & 17 & 8.2 & 0.21 & 0.05 & 0.07 & 4 & 0.1 & 0.1 & 0.0 & 2.5 & 2.7 & 2.8 & 0.94 & 0.93 \\
\hline S104402 & 206.95 & 2.7 & 6.6 & 94 & 76 & 35 & -0.13 & -0.21 & 0.13 & 0.15 & 4 & 19 & 8.5 & 0.28 & 0.10 & 0.10 & 3 & 0.1 & 0.1 & 0.0 & 2.0 & 2.2 & 3.0 & 0.73 & 0.94 \\
\hline 44,3 of 3 & 206.59 & & 5.7 & 77 & 72 & & -0.27 & -0.35 & 0.02 & 0.15 & 3 & 20 & 10 & 0.20 & 0.03 & 0.07 & 3 & 0.1 & & & & & 3.0 & & \\
\hline \multirow{2}{*}{\multicolumn{26}{|c|}{ a "Mo abundance, TOC, and DOP data from Scott et al. (2008); “"Mo, Al, TOC, and Fe speciation data from Li et al. (2010); "*'TOC data from McFadden et al. (2008). }} \\
\hline \multicolumn{24}{|c|}{ b $\mathrm{TOC}=$ total organic carbon. } & & \\
\hline \multirow{2}{*}{\multicolumn{26}{|c|}{ c Mo isotope data reported relative to RochMo2. }} \\
\hline & & & & & & & & & & & & & & & & & & & & & & & & & \\
\hline \multirow{2}{*}{\multicolumn{26}{|c|}{$\begin{array}{l}\text { e Uncertainty is the 2SD of replicate measurements or } 0.15 \% \text { whichever is greater. } \\
\text { f Number of replicate analyses of the same sample solution. }\end{array}$}} \\
\hline & & & & & & & & & & & & & & & & & & & & & & & & & \\
\hline \multicolumn{26}{|c|}{$\begin{array}{l}\text { f Number of replicate analyses of the same sample solution. } \\
{ }^{\mathrm{g}} \text { Uncertainty is the 2SD of replicate measurements or } 0.07 \% \text { whichever is greater. }\end{array}$} \\
\hline \multicolumn{26}{|c|}{ 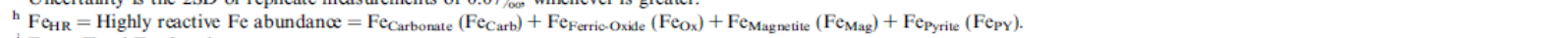 } \\
\hline
\end{tabular}


Table A.1

Geochemical data for the Black River Dolomite, Tasmania.

\begin{tabular}{|c|c|c|c|c|c|c|c|c|c|c|c|c|c|c|c|c|c|c|c|}
\hline Sample & $\begin{array}{l}\text { Depth } \\
\text { (m) }\end{array}$ & $\begin{array}{l}\text { TOC } \\
\text { (wt } \%)\end{array}$ & $\begin{array}{l}\mathrm{Al} \\
\text { (wt \%) }\end{array}$ & $\begin{array}{l}\text { Mo } \\
\text { (ppm) }\end{array}$ & $\begin{array}{l}\text { Mo } \\
\text { EF }\end{array}$ & $\begin{array}{l}\text { Mo/TOC } \\
\text { (ppm/wt\%) }\end{array}$ & $\begin{array}{l}\delta^{98} \mathrm{Mo}^{\mathrm{b}} \\
(\%)\end{array}$ & $\begin{array}{l}\delta^{98} \mathrm{Mo}^{\mathrm{c}} \\
(\%)\end{array}$ & $\begin{array}{l}\text { 2SD } \\
\text { Measured }\end{array}$ & $\begin{array}{l}2 \mathrm{SD}^{\mathrm{d}} \\
\text { Reported }\end{array}$ & $n^{e}$ & $\begin{array}{l}\mathrm{Fe}_{\text {Carb }} \\
(\mathrm{wt} \%)\end{array}$ & $\begin{array}{l}\mathrm{Fe}_{0 x} \\
(\mathrm{wt} \%)\end{array}$ & $\begin{array}{l}\mathrm{Fe}_{\mathrm{Mag}} \\
(\mathrm{wt} \%)\end{array}$ & $\begin{array}{l}\mathrm{Fe}_{\mathrm{PY}} \\
(\mathrm{wt} \%)\end{array}$ & $\begin{array}{l}\mathrm{Fe}_{\mathrm{HR}}{ }^{\mathrm{f}} \\
\text { (wt } \%)\end{array}$ & $\begin{array}{l}\mathrm{Fe}^{\mathrm{g}} \\
(\mathrm{wt} \%)\end{array}$ & $\begin{array}{l}\mathrm{Fe}_{\mathrm{HR}} / \\
\mathrm{Fe}_{\mathrm{I}}\end{array}$ & $\begin{array}{l}\mathrm{Fe}_{\mathrm{PY}} / \\
\mathrm{Fe}_{\mathrm{HR}}\end{array}$ \\
\hline $\begin{array}{l}\text { RC06- } \\
\text { FOR01-A }\end{array}$ & $\begin{array}{l}835.84- \\
835.87\end{array}$ & 5.1 & 4.8 & 14 & 15 & 2.7 & 1.15 & 1.07 & 0.06 & 0.15 & 3 & 0.1 & 0.1 & 0.0 & 2.7 & 2.9 & 2.8 & 1.00 & 0.94 \\
\hline $\begin{array}{l}\text { RC06- } \\
\text { FOR01-B }\end{array}$ & $\begin{array}{l}835.77- \\
835.79\end{array}$ & 5.6 & 4.7 & 14 & 16 & 2.5 & 1.20 & 1.12 & 0.10 & 0.15 & 3 & 0.1 & 0.1 & 0.0 & 2.5 & 2.6 & 2.6 & 0.99 & 0.95 \\
\hline $\begin{array}{l}\text { RC06- } \\
\text { FOR01-C }\end{array}$ & $\begin{array}{l}835.70- \\
835.72\end{array}$ & 5.3 & 5.4 & 14 & 14 & 2.6 & 1.23 & 1.15 & 0.10 & 0.15 & 3 & 0.1 & 0.1 & 0.0 & 3.1 & 3.3 & 2.9 & 1.00 & 0.96 \\
\hline $\begin{array}{l}\text { RC06- } \\
\text { FOR01-D }\end{array}$ & $\begin{array}{l}835.65- \\
835.68\end{array}$ & 5.6 & 5.1 & 12 & 13 & 2.2 & 1.18 & 1.10 & 0.13 & 0.15 & 3 & 0.1 & 0.1 & 0.0 & 2.6 & 2.8 & 2.8 & 0.98 & 0.95 \\
\hline $\begin{array}{l}\text { RC06- } \\
\text { FOR01-E }\end{array}$ & $\begin{array}{l}835.58- \\
835.62\end{array}$ & 5.3 & 5.1 & 12 & 13 & 2.3 & 1.17 & 1.09 & 0.06 & 0.15 & 3 & 0.1 & 0.1 & 0.0 & 2.5 & 2.7 & 2.6 & 1.00 & 0.95 \\
\hline $\begin{array}{l}\text { RC06- } \\
\text { FOR02-B }\end{array}$ & $\begin{array}{l}828.11- \\
828.15\end{array}$ & 6.5 & 7.0 & 29 & 22 & 4.5 & 0.61 & 0.53 & 0.10 & 0.15 & 3 & 0.1 & 0.1 & 0.0 & 3.0 & 3.3 & 4.1 & 0.79 & 0.93 \\
\hline $\begin{array}{l}\text { RC06- } \\
\text { FOR02-D }\end{array}$ & $\begin{array}{l}828.23- \\
828.27\end{array}$ & 6.6 & 5.7 & 29 & 27 & 4.4 & 0.63 & 0.55 & 0.18 & 0.18 & 6 & 0.1 & 0.1 & 0.0 & 3.0 & 3.3 & 4.1 & 0.80 & 0.93 \\
\hline $\begin{array}{l}\text { RC06- } \\
\text { FOR02-G }\end{array}$ & $\begin{array}{l}828.37- \\
828.40\end{array}$ & 6.5 & 7.4 & 33 & 24 & 5.1 & 0.54 & 0.46 & 0.21 & 0.21 & 6 & 0.1 & 0.1 & 0.0 & 3.4 & 3.6 & 4.5 & 0.80 & 0.93 \\
\hline $\begin{array}{l}\text { RC06- } \\
\text { FOR02-H }\end{array}$ & $\begin{array}{l}828.48- \\
828.50\end{array}$ & 6.4 & 5.6 & 30 & 29 & 4.7 & 0.47 & 0.39 & 0.10 & 0.15 & 3 & 0.1 & 0.1 & 0.0 & 3.3 & 3.6 & 4.0 & 0.90 & 0.93 \\
\hline $\begin{array}{l}\text { RC06- } \\
\text { FOR02-I }\end{array}$ & $\begin{array}{l}828.55- \\
828.58\end{array}$ & 6.8 & 7.3 & 29 & 21 & 4.2 & 0.62 & 0.54 & 0.12 & 0.15 & 4 & 0.1 & 0.2 & 0.0 & 2.9 & 3.3 & 4.0 & 0.81 & 0.90 \\
\hline
\end{tabular}

a $\mathrm{TOC}=$ total organic carbon.

${ }^{\mathrm{b}}$ Mo isotope data reported relative to Roch Mo2.

Mo isotope data reported relative to NIST SRM $3134=0.25^{\circ}$

${ }^{d}$ Uncertainty is the 2SD of replicate measurements or $0.15 \%$, whichever is greater.

e Number of replicate analyses of the same sample solution.

${ }^{\mathrm{f}} \mathrm{Fe}_{\mathrm{HR}}=$ Highly reactive $\mathrm{Fe}$ abundance $=\mathrm{Fe}_{\text {Carbonate }}\left(\mathrm{Fe}_{\mathrm{Carb}}\right)+\mathrm{Fe}_{\mathrm{Ferric}-\mathrm{Oxide}}\left(\mathrm{Fe}_{\mathrm{Ox}}\right)+\mathrm{Fe}_{\mathrm{Magnetite}}\left(\mathrm{Fe}_{\mathrm{Mag}}\right)+\mathrm{Fe}_{\mathrm{Pyrite}}\left(\mathrm{Fe}_{\mathrm{PY}}\right)$.

1219

${ }^{8} \mathrm{Fe}_{\mathrm{T}}=$ Total $\mathrm{Fe}$ abundance. 